\title{
SER MINA NO RIO DE JANEIRO DO SÉCULO XIX
}

Sandra Lauderdale Graham***

A

história deles foi uma história de casamento e divórcio, de reputações danificadas e esforços para restaurá-las. Henriqueta e Rufino tinham se casado em janeiro de 1855 na freguesia de Santa Rita, no Rio de Janeiro. Embora vivessem na freguesia, não eram de lá. Os dois eram africanos, trazidos de navio como escravos da região iorubá, na Costa da Mina, África Ocidental, para o porto da Bahia e, algum tempo depois, vendidos para novos senhores no Rio de Janeiro. Nunca saberemos que idades tinham quando foram levados da África, nem quanto tempo cada um permaneceu na Bahia, nem tampouco quando um e outro chegaram ao Rio. Sabemos somente que foi em torno de 1840 que, como escravos de diferentes senhores, Rufino e Henriqueta se conheceram e se tornaram amantes. Antes de casar, porém, compraram suas alforrias, primeiro Henriqueta, depois Rufino. Em

Esta é uma versão bastante revisada de artigo antes publicado em Slavery and Abolition, v. 32, n. 1 (2011), pp. 1-26, como "Being Yoruba in Nineteenth-Century Rio de Janeiro" publicado por Taylor \& Francis Ltd., http://www.informaworld.com, e traduzido com permissão do editor por Luana Amaral e Ana Carolina de Andrade Pinto. A autora agradece os comentários do parecerista de Afro-Ásia. João José Reis foi o primeiro a realmente instigar-me a pensar sobre as conexões africanas dessa história, e minha amiga e colega de trabalho de longos anos, Eugenia Herbert, generosa e sabiamente me guiou à literatura africana, bem como me introduziu aos estudos sobre maridos-fêmea. Russ Lohse dedicou o seu tempo para partilhar bibliografia pertinente comigo. De cada um aprendi muito, e cada um tem os meus grandes agradecimentos. Agradeço o Toyin Falola pela informação sobre coisas iorubàs. Mais uma vez agradeço aos membros do Seminário de Santa Fé por suas perspicazes observações.

** Professora aposentada da Universidade do Texas em Austin. 
junho de 1856, somente um ano e meio depois do casamento, Henriqueta pediu o divórcio eclesiástico, alegando ter sofrido ferimentos graves e "com perigo de sua vida," uma queixa que cabia, segundo as normas da Igreja, ouvir. ${ }^{1}$ As palavras, as categorias, as preocupações do seu processo estão todas em sintonia com as leis católicas e os costumes brasileiros, mas também podemos ouvir ecos de uma sensibilidade distintamente africana.

A história deles foi também um relato abrangente de identidades africanas remodeladas na escravidão e na liberdade no Brasil. A cultura mediterrânea, que se estende ao Brasil, na qual Henriqueta e Rufino tinham sido forçosamente inseridos como escravos, e na qual continuavam como pessoas libertas, lhes proporcionava modos de pensar sobre as expectativas de uma vida a dois, e um vocabulário para descrever o que lhes acontecia. Mas eles não estavam limitados a uma só cultura. Pertenciam, autenticamente, ao mundo Atlântico e carregavam, mesmo que de forma fragmentada ou imperfeitamente lembrada, os passados africanos do quais procediam. ${ }^{2}$

Henriqueta e Rufino chamavam um ao outro de "mina", o termo usado no Rio de Janeiro no Setecentos para todos os africanos ocidentais, incluindo os chamados daomeanos, falantes de várias línguas gbe, e os falantes de iorubá, oriundos de diversos grupos dentro do reino de

\footnotetext{
A história deles foi buscada nos seguintes processos legais: Juízo Eclesiástico, Henriqueta Maria da Conceição, preta Mina, contra Rufino Maria Baleta, preto Mina, Libelo de Divórcio, Rio de Janeiro, 1856 (doravante, Divórcio, 1856), Arquivo da Cúria Metropolitana, Rio de Janeiro (doravante, ACM-RJ), Libelo de Divórcio, 1174, Caixa 68; Juízo Eclesiástico, Rufino Maria Baleta, preto Mina, justificante, contra Henriqueta Maria da Conceição, preta Mina, justificada, Justificação para Remoção do Depósito (doravante, Justificação, 1856), em Libelo de Divórcio, Rio de Janeiro, 1856, ACM-RJ, Libelo de Divórcio, 1174, Caixa 68 [paginado separadamente]; Juízo da $2^{\mathrm{a}}$ Vara Cível, Divórcio, Rufino José Maria Baleta, réu, Rio de Janeiro, 1857 (doravante, Divórcio, 1857), Arquivo Nacional, Rio de Janeiro (doravante, AN-RJ), Seção do Poder Judiciário (doravante, SPJ), Maço 877, n. 686 [transcrito, s.p.]; Juízo Municipal da $3^{a}$ Vara Cível, Inventário, Rofino Joze Maria Baleta e Henriqueta Maria da Conceição, Rio de Janeiro, 1858 (doravante, Inventário, 1858), AN-RJ, SPJ, Caixa 300, no. 828 , Gal. A

2 João José Reis, Flávio dos Santos Gomes e Marcus J. M. de Carvalho, O Alufá Rufino: tráfico, escravidão e liberdade no Atlântico negro, c. 1821 - c. 1853, São Paulo: Companhia das Letras, 2010; Lisa Earl Castillo e Luis Nicolau Parés, "Marcelina da Silva: A NineteenthCentury Candomblé Priestess in Bahia", Slavery and Abolition, v. 31, n. 1 (2010), pp. 1-27; Robin Law e Kristin Mann, "West Africa in the Atlantic Community: The Case of the Slave Coast", William and Mary Quarterly, v. 56, n. 2 (1999), pp. 307-34.
} 
Oyó ao norte e vários estados vizinhos ao sul. Os povos de fala iorubá na África tinham sido severamente afetados pela guerra que minava a liderança dos reis de Oyó e, no período aqui tratado, já eram maioria entre os minas do Rio de Janeiro. Para os não-africanos ou para os africanos centro-ocidentais e orientais no Brasil, mina era um rótulo conveniente, e até simplificador, mas, para estes minas, a palavra fazia lembrar, especificamente, os costumes dos iorubá-falantes que os distinguiam dos outros africanos no Rio. Porque Henriqueta e os outros usavam o termo mina para se identificarem, refiro-me a eles como mina, mas, ao longo do texto, também uso iorubá para enfatizar a ampla cultura a que pertenciam. Aqui, quero descobrir um pouco do que, no contexto brasileiro, significava ser "preto(a) mina" oriundo(a) da África iorubá.

Os historiadores têm ultimamente debatido se os costumes africanos permaneceram significativos para os escravos nas Américas. Philip Morgan nos alerta contra a suposição de que as identidades étnicas africanas tenham cruzado prontamente o Oceano Atlântico, ou, até mesmo, que a identidade étnica tenha permanecido intacta quando os cativos foram capturados no interior da África, obrigados a marchar para a costa e dali exportados. Nem poderiam "essas identidades facilmente permanecerem imaculadas nas Américas pluralistas”, diz ele. É melhor pensarmos na formação cultural não como transferência, mas como "empréstimo e adaptação, modificação e invenção". E João Reis complementaria, como "negociação". Morgan pede que foquemos a nossa atenção "em fronteiras fluidas, em zonas de interação precárias e permeáveis, em sociedades híbridas, em mosaicos de divisas nas quais culturas se acotovelavam e convergiam em combinações e permutas de complexidade estonteante". ${ }^{3}$ John Thornton, tomando uma posição contrária, insiste que escravos de uma dada zona cultural ou grupo linguístico podiam conservar laços com sua parentela cultural, e assim o faziam, mantendo viva a identidade africana nas Américas. Escravos, ele diz, eram tipicamente de uma "zona restrita e culturalmente bastante homo-

Philip D. Morgan, "The Cultural Implications of the Atlantic Slave Trade: African Regional Origins, American Destinations and New World Developments", Slavery and Abolition, v. 18, n. 1 (1997), pp. 122-45, 134, 136 (citações), 142; João José Reis, Rebelião escrava no Brasil: a história do levante dos malês em 1835, São Paulo: Companhia das Letras, 2003, p. 310. 
gênea", mesmo que esta fosse geograficamente dispersa, e os comerciantes os desembarcavam em grandes lotes, geralmente num mesmo porto. David Eltis enfatiza que "o comércio era muito mais frequentemente limitado a uma região do que é comum se pensar". Além disso, misturar diferentes grupos culturais de escravos, mesmo quando os senhores o desejassem, era difícil se a carga humana não era diversa. "A maioria dos escravos", ele conclui, "acharia muitas pessoas de sua nação com quem se comunicar e talvez compartilhar elementos de uma cultura comum". Entre eles, culturas africanas específicas poderiam ser "continuadas e desenvolvidas" em novos cenários e, ainda, "transmitidas para as próximas gerações". Vincent Brown sugere abandonar a busca por "sistemas de crenças completos e integrados", preferindo, ao invés disso, uma noção mais flexível de cultura na qual as "práticas de significação são mais bem vistas como ferramentas a serem usadas do que como bens a serem perdidos" e condicionadas às reais circunstâncias que os africanos enfrentavam como escravos. ${ }^{4}$

Há algo mais a ser dito, porém, porque qualquer que tenha sido a dinâmica da formação cultural, a memória construía uma ponte crucial entre os passados que eles carregavam e o presente para o qual foram levados. O passado lembrado pelos africanos lhes serviu (assim como o nosso nos serve) como ponto de referência, uma âncora para saberem quem eles eram e para se reinventarem em circunstâncias radicalmente alteradas e incertas. Um escritor refere-se à memória como uma "inconstante e irreproduzível rede de experiência e associações das quais nós construímos o que somos, quem os outros são, e o que podemos esperar deles e de nós mesmos". 5 As identidades anteriores não eram

John Thornton, Africa and Africans in the Making of the Atlantic World, 1400-1800, Cambridge: Cambridge University Press, 1998, pp. 186-90, 192, 195, 197; David Eltis, "The Volume and Structure of the Transatlantic Slave Trade: A Reassessment", William and Mary Quarterly, v. 58, n. 1 (2001), p. 31. Robert S. Smith, Kingdoms of the Yoruba, Londres: Methuen, 1976, pp. $11,14,115,243-44$, discute que a cultura e a língua iorubá emergiram de forma complexa, mas coerente; Thornton acrescenta que o iorubá se tornou uma língua franca para grande parte da costa oeste africana até os anos 30 do século XVII, "Traditions, Documents, and the Ife-Benin Relationship", History in Africa, n. 15 (1988), p. 358; ver também, Biodun Adediran, "Yoruba Ethnic Groups or a Yoruba Ethnic Group? A Review of the Problem of Ethnic Identification", Africa, n. 7 (1984), pp. 57-70; Vincent Brown, "Social Death and Political Life in the Study of Slavery", American Historical Review, v. 114, n. 5 (2009), p. 1245.

Michael Greenberg, "Just Remember This", New York Review of Books, v. 55, n. 19 (2008), p. 10. 
subitamente apagadas. Pelo contrário, novas camadas de compreensão e formas de reagir eram adicionadas. A memória era o elo essencial entre o passado e o presente. E, sendo assim, torna-se esclarecedor reconstruir esse passado africano lembrado.

Resgatar o conteúdo da memória não é algo simples de fazer. Fontes brasileiras, embora tendendo para a linguagem jurídica, proporcionam indícios de como esses dois africanos realmente se chamavam e se localizavam nesse lugar até então inimaginável. Tendo em vista uma cultura então sem escrita, onde não havia localmente qualquer documentação escrita que ligasse os escravos no Brasil a seu passado antes da escravidão, mesmo se seus nomes africanos fossem conhecidos, o passado iorubá preciso e particular de Henriqueta e Rufino está, para nós, para sempre perdido. As fontes escritas que existem são distanciadas, vindas de forasteiros britânicos e americanos que viajaram por lá entre 1820 e 1850 como exploradores e naturalistas, como missionários e comerciantes. Eles escreveram sobre o que viram, com mais ou menos detalhes, com muita ou pouca sensibilidade. E, embora essas fontes insubstituíveis, imperfeitas e recalcitrantes desafiem conclusões seguras, posso expor possibilidades e unir contextos para chegar a um passado plausível, do qual nossos personagens puderam partir para dar sentido a um presente desconhecido, confuso ou ameaçador. Assim como os senhores de escravos descartavam a experiência africana, por ser sem interesse, muitos historiadores se mostraram indiferentes por considerar o passado de um escravo como algo além de nosso alcance documental. Recuperar ao menos o simples contorno do passado destes africanos nos lembra quão incompletas as histórias dos escravos permanecem e quão urgente é a tarefa.

\section{Sair da África}

"Mina" tinha muitos significados. A extensa costa do golfo do Benin, desde o rio Volta até o delta do rio Níger, região conhecida como Costa da Mina, recebeu este nome por causa do forte português São Jorge da Mina (nome posteriormente modificado para Elmina), estabelecido em 1482 com o objetivo inicial de comercializar ouro, marfim e pimenta. Originalmente, a região incluía a costa a oeste do rio Volta, até o forte. 
Posteriormente esta área se tornaria a Costa do Ouro, enquanto a Costa da Mina também veio a ser conhecida pelos europeus - à exceção dos portugueses - como Costa dos Escravos, quando, mais tarde, os comerciantes concentraram suas energias no tráfico de escravos, especialmente durante os primeiros três quartos do século XVIII e, de novo, nas primeiras décadas do XIX. ${ }^{6} \mathrm{O}$ tráfico legal de escravos com o Brasil nessa região se prolongou até 1817, quando, através de um tratado com Portugal, os britânicos o baniram ao norte da linha do Equador e adquiriram, em 1819, o direito de fazer buscas em navios suspeitos e de confiscar suas cargas. Quando, em 1831, a importação de quaisquer africanos para o Brasil se tornou ilegal, e o Brasil, já país independente, concedeu o direito de execução dessa lei no alto mar aos ingleses, o número de escravos traficados diminuiu por um tempo. ${ }^{7}$ Entretanto, navios saídos de portos da Costa da Mina - Pequeno Popo, Grande Popo, Uidá, Porto Novo, Badagri, Lagos e outros - levavam centenas de milhares de homens, mulheres e crianças para as Américas, principalmente para Cuba e Brasil. No Brasil, a maioria seguia para a Bahia. ${ }^{8}$

Saber o porto, contudo, não identifica precisamente os lugares onde os africanos tinham sido originalmente capturados e destinados à venda, e não define quem eles eram. Poderiam ter vindo do reino de

6 Pierre Verger, Trade Relations between the Bight of Benin and Bahia, 17th to 19th Century, Ibadan: Ibadan University Press, 1976, pp. 11, 367; Robin Law, "Ethnicities of Enslaved Africans in the Diaspora: On the Meanings of 'Mina' (Again)", History in Africa, v. 32 (2005), pp. 248-49, 251; Thornton, Africa and Africans, pp. 26-32, 119.

7 Leslie Bethell, The Abolition of the Brazilian Slave Trade: Britain, Brazil and the Slave Trade Question, 1807-1869, Cambridge: Cambridge University Press, 1970, esp. pp. 18-9, 122 e 62-87; Verger, Trade Relations, pp. 278-81.

8 David Eltis, "The Nineteenth-Century Transatlantic Slave Trade: An Annual Time Series of Imports into the Americas Broken Down by Region", Hispanic American Historical Review (doravante, $H A H R$ ), v. 67, n. 1 (1987), pp. 109-20; David Eltis, "The Diaspora of Yoruba Speakers, 1650-1865: Dimensions and Implications", in Toyin Falola e Matt D. Childs (orgs.), The Yoruba Diaspora in the Atlantic World (Bloomington: Indiana University Press, 2004), pp. 17-39, 24 (Tabela 2.3); Paul E. Lovejoy, "The Yoruba Factor in the Trans-Atlantic Slave Trade", in Falola e Childs (orgs.), The Yoruba Diaspora, pp. 40, 43-4; Manolo Florentino, Em costas negras: uma história do tráfico Alântico de escravos entre África e o Rio de Janeiro (séculos XVIII e XIX), Rio de Janeiro: Arquivo Nacional, 1995, pp. 51-4, 85-7 e 263, Apêndice 13; Mary C. Karasch, Slave Life in Rio de Janeiro, 1808-1850, Princeton: Princeton University Press, 1987, p. 25, 15 (Tabela 1.6), 52 (Tabela 2.5); Mariza de Carvalho Soares, "From Gbe to Yoruba: Ethnic Change and the Mina Nation in Rio de Janeiro", in Falola e Childs, The Yoruba Diaspora, pp. 235-9, salienta (p. 236) que se aqueles comercializados da Bahia para o Rio fossem incluídos, o número de africanos do oeste seria ainda maior. 


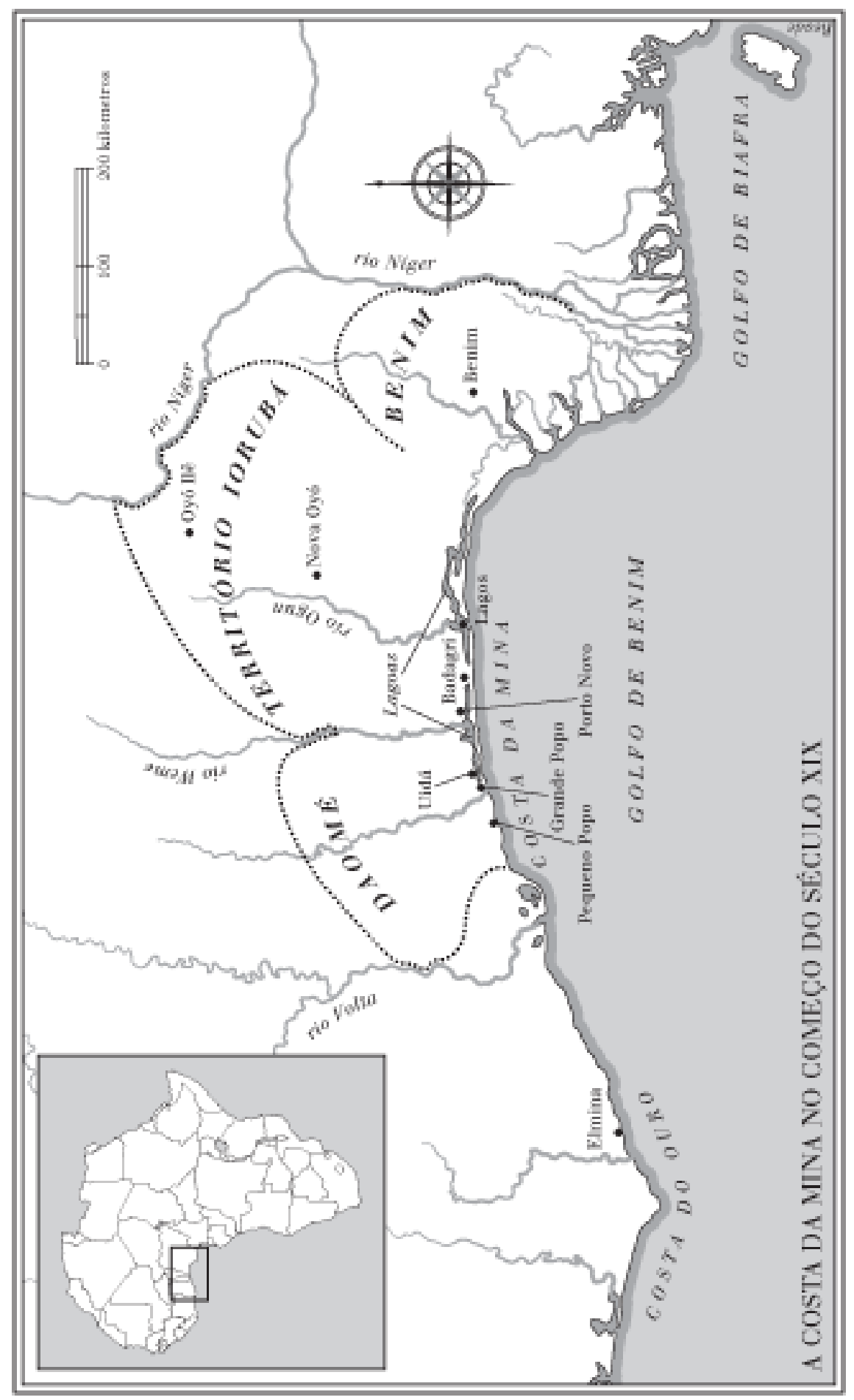


Daomé, ou de qualquer um dos muitos reinos ou cidades-estado tributários de Oyó, ou dos estados da confederação iorubá, que seguiu ao colapso de Oyó nos anos 1820, fracamente unidos por tradições culturais e linguísticas comuns e transformadas pela guerra. Poderiam ter sido nupes, haussás, bornos, borgus, ou os fulanis do norte do rio Níger, ou da confederação Mahi, região imprensada entre os daomeanos e os iorubás. Alguns eram falantes do gbe, outros falavam iorubá ou qualquer dos vários dialetos relacionados. ${ }^{9} \mathrm{E}$ ainda, entrelaçada com essas questões, tornando mais complexa a distinção de quem era quem, estava a religião. Os minas podiam ser mulçumanos haussás, ou fulanis e, com menor fequência, iorubás convertidos ao Islã; podiam ser devotos dos deuses voduns dos daomeanos, dos orixás iorubás, ou de Alá. Uma vez do outro lado do Atlântico, qualquer um poderia se chamar mina, suavizando as precisas e ferozes diferenças antigamente tão vivamente sentidas e que tinham provocado a guerra e a escravidão entre eles em suas terras natais. Saber quem eram os minas dependeria de saber do tempo e das circunstâncias da captura. Saber de onde eles vinham tem que ser rastreado na sucessão de eventos que tragaram a Costa da Mina na primeira metade do século XIX.

Os padrões da escravização mudaram desde o início do século XVIII até meados do XIX, mudança incitada não apenas por uma explosão na demanda por escravos nas Américas, mas também por causa da guerra e da política entre e dentro dos reinos da costa e do interior. Como o centro do poder se movia na direção leste, de Daomé - que conquistara a costa em 1727 - para Oyó, o comércio seguia o mesmo caminho, transferindo suas operações de Uidá para os portos de Porto Novo, Badagri e Lagos. Escravos eram comprados, caçados ou capturados na guerra e eram levados a pé por terra ou atravessavam de canoa uma rede de lagunas até os portos, onde negociantes pagavam por eles com sal, peixe e goma, assim como artigos de luxo, tais como tecido, contas de coral, tabaco baiano, búzios cauris usados como moeda, bar-

\footnotetext{
Smith, Kingdoms of the Yoruba, pp. vii-ix, 57-109, esp. 87, inclui Oyó entre 13 reinos, e pp. 11, 14, 114-5, 243-4; Robin Law, The Oyo Empire, c. 1600-1836: A West African Imperialism in the Era of the Atlantic Slave Trade, Oxford: Clarendon Press, 1977, pp. 4-7, 85-118, esp. 4-5, inclui Oyó entre 17 reinos.
} 
ras de ferro e armas. Gradativamente, durante os primeiros três quartos do século XVIII, o reino de Oyó veio a ser o principal fornecedor de escravos dos portos do leste do golfo do Benin. ${ }^{10}$ Mas, quando alcançou sua expansão máxima, na década de 1780, sua decadência já começava a se manifestar. A derrota infligida por seus vizinhos ao norte, nas décadas de 1780 e 1790, foi agravada quando os chefes em Oyó, competindo pela nova riqueza gerada pelo tráfico, ficaram sedentos de poder e rebelaram-se de dentro do império, jogando as províncias contra o centro. E, a partir de 1796, a desintegração "acelerou-se e tornou-se irreversível”. Em 1817, uma jihad isolou o centro do império de Oyó e fez os moradores locais fugirem, inchando as vilas ao sul da floresta. Nas décadas de 1810 e 1820, um redemoinho de guerras civis deixou as vilas destruídas ou despovoadas. Os reinos do entorno também se revoltaram. ${ }^{11}$ Em meados dos anos 1830, o antigo império de Oyó já estava em pedaços, sua capital, Oyó Ilê, abandonada.

Para os iorubás, o "acotovelamento e convergência" começou na terra natal, antes mesmo de eles de lá saírem. Mercadores iorubás tinham sempre se deslocado de um lado a outro de fronteiras mal desenhadas, atravessando limites imprecisos dos territórios vizinhos, cada um com costumes e dialetos diferentes. A guerra prolongada intensificou a diluição, a mistura, o peneiramento das diferenças regionais, quando grande parte da população fugia para as cidades localizadas ao sul. No tumulto do deslocamento, com rotas de comércio interrompidas e exércitos de escravos em revolta, os traficantes iorubás de escravos deixaram de limitar suas presas a regiões vizinhas e passaram a adquirir cativos dentro do próprio território iorubá. ${ }^{12}$ A estratégia deles fica cla-

${ }^{10}$ Law, Oyo Empire, pp. 16, 173-4, 182, 222-8, 307-8; Smith, Kingdoms of the Yoruba, pp. 151, 145-6, e uma cronologia, pp. 174-5; Robin Law, "Trade and Politics behind the Slave Coast: The Lagoon Traffic and the Rise of Lagos, 1500-1800", Journal of African History, v. 24, n. 3 (1983), pp. 336-8, 347; Ann O'Hear, "The Enslavement of Yoruba", in Falola e Childs. The Yoruba Diaspora, pp. 57-61; Verger, Trade Relations, pp. 1-7.

11 Smith, Kingdoms of the Yoruba, p. 160 (citação), pp. 147, 159, 165, 171, 173, 174-177; Law, Oyo Empire, pp. 250-5, 271, 278, 278-99, 305-10; T[homas]. J[efferson]. Bowen, Central Africa. Adventures and Missionary Labors in Several Countries in the Interior of Africa, from 1849 to 1856, Nova York: Negro Universities Press, 1969; primeira edicão de 1857, pp. 113-4.

12 Law, Oyo Empire, p. vii, 308; O'Hear, “The Enslavement of Yoruba”, pp. 64-7; Bowen, Central Africa, p. 113. 
ra no número de cativos exportados. Com um brigue brasileiro ancorado em Badagri aguardando para embarcar escravos, "as pessoas aqui têm se preparado por dois dias para uma expedição escravista" até uma vila próxima, escreveu um viajante britânico, em 1825. A princípio, 92\% dos escravos do golfo do Benin zarpavam de Uidá, e nenhum de Lagos. Mas em meados dos anos 30 e 40 do século XIX o comércio de Uidá já tinha decaído, e 59\% dos navios partiam de Lagos. Se aceitarmos que os cativos eram levados para a costa pela rota mais direta - a mais barata, mais rápida e mais segura para seus captores -, que embarcavam pelo porto mais próximo do local de sua captura, e que normalmente se carregavam os navios em um único porto em cada viagem, então no século XIX os falantes do iorubá constituíam, evidentemente, a maioria entre os exportados. ${ }^{13}$ Mesmo aqueles escravos embarcados em Uidá, depois de 1823, eram provavelmente iorubás capturados por daomeanos em retaliação a um reino Oyó desintegrado.

Uma vez fora da África, para onde esses iorubás seriam vendidos? De cerca de 468.800 cativos iorubás enviados para as Américas entre 1800 e 1850, uns 291.400, ou seja, 62\% desembarcaram na Bahia, onde eram conhecidos como nagôs. Nas listas de escravos em inventários de senhores falecidos em Salvador, nos anos 1820, somente 16\% dos escravos nascidos no oeste africano foram registrados como falantes iorubás. Quinze anos depois, iorubás já representavam 31\%, e na década de $1850,86 \% .^{14}$

13 Hugh Clapperton, Journal of a Second Expedition into the Interior of Africa from the Bight of Benin to Soccatoo, to which is Added The Journal of Richard Lander from Kano to the Sea-Coast, Partly by a More Eastern Route, Londres: Frank Cass \& Co., 1966; primeira edição de 1829, p. 13; Eltis, "The Diaspora of Yoruba Speakers", in Falola e Childs, Yoruba Diapora, pp. 24, 18-19, 20-6. Sobre o crescimento da dominação de Lagos como porto escravista, ver Law, "Trade and Politics behind the Slave Coast", pp. 321-48; Kristin Mann, Slavery and the Birth of an African City: Lagos, 1760-1900, Bloomington: Indiana University Press, 2007, pp. 39-82; Thornton, Africa and Africans, pp. 192-5; e, especialmente, Eltis, "A Reassessment", pp. 31-3.

14 Eltis revisou os dados em "The Diaspora of Yoruba Speakers", in Falola e Childs, Yoruba Diaspora, pp. 30-1 (Tabela 2.5), p. 29; Verger, Trade Relations, pp. 1-7, Sobre o comércio de minas, João José Reis e Beatriz Gallotti Mamigonian dizem 88\%; "Nagô and Mina: The Yoruba Diaspora in Brazil", in Falola e Childs, Yoruba Diaspora, pp. $78-9$ (Tabela 5.1), p. 80, 106; Carlos B. Ott, Formação e evolução étnica da cidade do Salvador, Salvador: Tipografia Ltda., 1955, vol. 2, pp. 91-2 (Apêndice III, Tabelas 2 e 3), vol. 1, pp. 61, 68. 
Apesar de a venda de escravos para a Bahia ter caído imediatamente depois de 1831, a partir dos anos 1840 um comércio clandestino febril novamente tinha se instalado, mas com a diferença de que os navios não mais navegavam livremente para os cais de Salvador. Henriqueta e Rufino, como outros de sua nação, desembarcariam clandestinamente na praia de Itapuã, em outras praias ao norte de Salvador, na ilha de Itaparica na entrada da baia, ou talvez num cais privado da cidade protegido pela escuridão e por alguma autoridade policial. Um navio atracou com 575 escravos, outro trouxe 380 e, sem precedentes, 1.350 escravos chegaram à Bahia no dia 4 de maio de 1846, numa afronta desavergonhada à lei e para a ira do sempre vigilante cônsul britânico. ${ }^{15}$ Os números aumentaram. Entre 1831 e 1850, pelo menos 116.671 africanos chegaram a Salvador, em média cerca de seis mil por ano. Pelo menos 162 navios saíram de Lagos, ou de outros portos do golfo do Benim, durante esses anos, antes de o comércio ser definitivamente fechado, no início da década de 1850, quando os brasileiros passaram uma nova lei antitráfico e desta vez a fizeram cumprir, ao mesmo tempo em que os britânicos bloqueavam a exportação de africanos de Lagos, favorecendo o "comércio legítimo" de azeite-de-dendê.

Nada nas fontes revela exatamente quando Henriqueta e Rufino chegaram à Bahia, ou quando cada um foi vendido para o Rio de Janeiro. Somente é sabido que, antes de se casarem, em 1855, eles se conheceram no Rio e começaram, provavelmente em meados da década de 1840, uma relação "ilícita" que duraria de oito a dez anos (seus depoimentos sobre o assunto são inconsistentes). Essa evidência os coloca como mercadoria no comércio transatlântico quando as guerras civis no território iorubá ganhavam ímpeto e o tráfico da Costa da Mina se intensificava nos anos 1830 e 1840 - o que os situa como sendo reexportados da Bahia na rota do "intenso comércio de escravos para o sul" do início dos anos $1840 .{ }^{16}$

15 Verger, Trade Relations, pp. 377-80, 396, e 420 n. 1; Bethell, Abolition of the Brazilian Slave Trade, pp. 391-5.

16 Eltis, Economic Growth, pp. 244 (Tabela A.1), 250-1 (Tabela A.9), 253 (Tabela A.10), 249 (Tabela A.8); Eltis, "The Nineteenth-Century Transatlantic Slave Trade", pp. 113, 114-5 (Tabela I), 116-7, 136 (Tabela V), 118-9; Mann, Slavery and the Birth of an African City, p. 38 (Tabela 1.2), para os números revisados e acresentados; Reis e Mamigonian, "Nagô and mina", in Falola e Childs, Yoruba Diaspora, p. 90 (citação). 
No Rio de Janeiro, onde Henriqueta e Rufino acabaram se estabelecendo, os minas eram poucos, somente em torno de $7 \%$ dos escravos africanos entre os anos de 1833 e 1849, comparados à esmagadora presença de $67 \%$ de falantes de línguas bantas de Angola e do Congo, e 17\% de africanos do leste, na sua maioria de Moçambique. Somente uma pequeníssima parte dos minas chegava ao Rio de Janeiro diretamente da Costa da Mina, pois a maioria vinha através da Bahia. Em 1849, quando o número de escravos africanos no Rio estava em seu auge, perfazendo 52.341, os minas foram contabilizados em apenas 3.664. Pelo menos outros 531 escravos libertos eram também minas, totalizando, aproximadamente, 4.200. ${ }^{17}$ Até os anos 1840 e 1850 a maioria deles era iorubá. Henriqueta e Rufino pertenciam a essa pequena comunidade de pretos minas.

\section{Tornando-se brasileiro}

Os africanos não trocavam de identidade como se troca de roupa, mas, ao invés disso, adicionavam novas camadas identitárias à que já tinham. As percepções mudavam e as reações eram alteradas. Eles adquiriam novos conhecimentos, mais apropriados a esse novo lugar. Inevitavelmente, tais mudanças se deram, sobretudo, nas definições de trabalho. Afinal, o trabalho preenchia a maior parte das horas de seus dias, e aqui eles tinham de falar uma nova língua, praticar novas habilidades e empunhar ferramentas desconhecidas. Todos sentiam a experiência esmagadora e humilhante de ser escravo, mesmo se alguns conquistavam pequenos espaços de autonomia. Alguns trabalhavam no ganho com a possibilidade de poupar dinheiro suficiente para comprar a alforria, manobrando por entre os rigores da escravidão, e, depois de algum tempo, muitos aprendiam a lidar com os desafios da liberdade. Mas, primeiro, tornar-se brasileiro era o que os africanos faziam para sobreviver.

17 As origens dos 9\% restantes eram desconhecidas. Karasch, Slave Life, pp. 15 (Tabela 1.6, para os anos 1832 e 1833-1849), 12 (Tabela 1.2), e 25, 26-7; Reis e Mamigonian, "Nagô and Mina", in Falola e Childs, Yoruba Diaspora, p. 102; Manolo Florentino, "Alforria e etnicidade no Rio de Janeiro oitocentista: notas de pesquisa”, Topoi, v. 5 (2002), pp. 27-8 (Tabela 2); Florentino diz que entre 1 e $2 \%$ vieram direto para o Rio de Janeiro, Costas negras, p. 86 (Gráfico 9); Recenseamento do Rio de Janeiro, 1849, Mapa 4, Santa Rita, e Mapa 9, Freguesias da Cidade, AN-RJ, GIFI [coleção de manuscritos não catalogados] 5B 447 (doravante, Rencenseamento, Rio de Janeiro, 1849). 
Ambos, Henriqueta e Rufino, começaram na Bahia. Rufino viveu em Nossa Senhora do Resgate das Umburanas, uma freguesia rural do interior, no limite do Recôncavo da Bahia, parte do grande município de Cachoeira, produtor de fumo em grande escala. Aqui os lavradores não eram, tipicamente, ricos senhores de engenho, donos de vastas terras e dezenas ou, até mesmo, centenas de escravos. O senhor de Rufino provavelmente possuía menos de quarenta hectares e não mais de dez ou vinte escravos, talvez até tivesse menos de vinte hectares e somente quatro ou cinco escravos. Rufino não somente trabalhava e vivia com um pequeno grupo de parceiros escravos - uma das consequências disso era ter menos chance de achar uma esposa - mas, provavelmente, menos de $20 \%$ desses eram nascidos na África, ficando ele entre estranhos. Rufino provavelmente cultivava tabaco, inclusive o tipo de tabaco de segunda classe que era exportado para a costa oeste da África e ali trocado por escravos. O declínio da importação de escravos africanos pela Bahia depois de 1830, que durou até o final da década, significou uma correspondente queda na demanda por tabaco. Diante dessa crise, o senhor de Rufino pode ter achado prudente vender um de seus escravos, e escolheu o africano. ${ }^{18}$

Henriqueta viveu uma vida muito diferente na Bahia. Ela se misturava diariamente com negros, brancos e mulatos, escravos e libertos, na freguesia de Nossa Senhora do Pilar, contígua ao porto e centro comercial de Salvador, na Cidade Baixa, que era populosa, barulhenta e completamente urbanizada. Não era a freguesia mais pobre, nem a mais rica, mas uma confusão de prósperos comerciantes portugueses, trabalhadores de uma fábrica de sabão, pescadores, um tabelião, um farmacêutico, joalheiros, um advogado, um tipógrafo, comerciantes de escravos e, especialmente, curtidores de couro. Ela e os demais escravos constituíam um terço da população. Essa variedade social era refletida na arquitetura das grandes residências, nos galpões, nas prensas de algodão, em prédios de dois, três e, às vezes, quatro andares nos quais viviam várias famílias, ou em moradias sobre as lojas, tudo vigiado por

18 B. J. Barickman, A Bahian Counterpoint: Sugar, Tobacco, Cassava, and Slavery in the Recôncavo, 1780-1860, Stanford: Stanford University Press, 1998, pp. 12, 13, 31, 110, 136-7, $149-50,157-61$. 
sete igrejas. Talvez Henriqueta trabalhasse como doméstica em uma das casas finas, ou não tão finas assim. O mais provável é que vendesse comida ou bugigangas na rua, como ganhadeira, comprando estoques de frutas ou vegetais numa feira na praia, perto do cais, onde os produtos agrícolas, trazidos do outro lado da baía, eram descarregados. ${ }^{19}$

Tendo sido vendido para o Rio de Janeiro, e obrigado a encarar a assustadora incerteza de um senhor desconhecido num lugar estranho, Rufino se tornou propriedade de um negociante de importação e exportação, José Maria Warleta (às vezes escrito Baleta), com um escritório no centro da cidade. Ao invés de trabalhar diretamente nos negócios de Warleta, Rufino era um investimento, negro de ganho. Tudo o que ganhava além da quantia semanal, devida a Warleta, era dele e, como muitos escravos que trabalhavam por conta própria, ele provavelmente vivia "sobre si", longe da casa do seu senhor, comprando sua própria comida e pagando seu próprio aluguel, possivelmente trabalhando no que continuaria a fazer mais tarde, como liberto. A situação de Rufino mudou radicalmente, em abril de 1854, quando comprou a Warleta sua liberdade.

Pelo menos a partir desse momento, Rufino, um "pombeiro", vendia peixe e aves. Uma postura municipal impedia os vendeiros de montar livremente barracas em qualquer lugar da cidade, e exigia que o fizessem somente na Praça do Mercado, um mercado central onde as autoridades supunham que horário regular de funcionamento e padrões de higiene poderiam ser impostos mais efetivamente. Uma postura municipal prescrevia que, no centro do mercado, ficariam os vendedores de vegetais, aves e ovos, enquanto que, no lado da rua, estariam os que lidavam com cereais, legumes, farinha de mandioca e cebola. Peixes fresco e salgado seriam vendidos na faixa próxima ao mar, chamada de

19 Rufino [Maria Baleta] e Henriqueta [Maria da Conceição], Rio de Janeiro, 16 de janeiro de 1855, Casamentos, Freguezia de Santa Rita, Livro 5 (1852-1860), ACM-RJ, AP552, fls. 40v1; sobre o mercado, Câmara para o Governador, Salvador, Bahia, 14 de junho de 1809, Arquivo Público do Estado da Bahia (doravante APEB), Colônia e Província, Cartas do Senado para o Governo, 1809, maço 127; sobre o Pilar, Anna Amélia Vieira Nascimento, Dez freguesias da cidade do Salvador: aspectos sociais e urbanos do século XIX, Salvador: Fundação Cultural do Estado da Bahia, 1986, pp. 33, 37-8, 90-92, 143-6; sobre o papel dos vendedores de rua no abastecmento de Salvador, ver Richard Graham, Feeding the City: From Street Market to Liberal Reform in Salvador, Brazil, 1780-1860, Austin: University of Texas Press, 2010, esp. pp. 33-73. 
Praia do Peixe. O nome de Rufino não aparece na lista do fiscal da freguesia nem dos vendedores licenciados em 1854. Ao invés disso, ele carregava um papel da câmara municipal, autorizando-o a vender em praça pública. ${ }^{20}$ Operava em pequena escala e, provavelmente, nas margens do mercado, onde sumia no meio da algazarra geral.

No Rio de Janeiro, Henriqueta vendia produtos agrícolas - geralmente frutas - nas ruas da freguesia de Santa Rita, algumas vezes na estratégica Rua Direita ou no Largo do Rosário, e outras vezes em casa. Desde quando Rufino a conheceu, era o que ela fazia, primeiro como escrava, depois vendendo por sua própria conta, a partir de 1853, quando comprou sua liberdade. Durante aqueles anos, ao invés de possuir ou alugar sua própria barraca, ela trabalhava nas ruas, de porta em porta, com uma cesta larga equilibrada na cabeça e, até para isso, a câmara municipal exigia dela uma licença. ${ }^{21}$ Henriqueta era ambiciosa e, decerto, desejava ter sua própria barraca.

Vender na rua e no mercado impulsionou os dois africanos tanto para transações de crédito negociadas cara-a-cara, baseadas na confiança, quanto para a concorrência que poderia destruí-la. Rufino, provavelmente, comprava peixe de manhã cedo, diretamente das canoas que puxavam as redes cheias até a praia, e ia até o campo para obter aves domésticas. Henriqueta comprava de fornecedores no mercado. Ele não possuía barco, nem pescava na beira mar, ou criava galinhas, e ela não cuidava de uma horta para obter as frutas e os vegetais que vendia. A ambos faltava capital para comprar o que vendiam, de modo que ou tomavam empréstimos ou compravam a crédito. Nenhum deles declarou quanto dinheiro estava envolvido ou quem eram seus fornecedores,

${ }^{20}$ Almanak administrativo, mercantil e industrial, Rio de Janeiro (Rio de Janeiro: Laemmert, 1854), p. 414, 503 (doravante Almanak Laemmert, 1854); Guia do Rio de Janeiro ou Indicador Alphabetico (Rio de Janeiro: Laemmert, 1860), p. 97; Carta de Liberdade conferida por José Maria Warleta a Rufino, 2 de abril de $1854,2^{\circ}$ Ofício de Notas, Rio de Janeiro, Registro Geral, Livro 87 (16/01/1854-07/08/1854), AN-RJ, fl. 79 (doravante, Carta de Liberdade, Rufino, 1854); Divórcio, 1856, fls. 9,15; Divórcio, 1857, traslado.

21 Justificação, 1856, fls. 14, 16v., 18; Divórcio, 1856, fls. 35, 13v.; Carta de Liberdade que dá Roza Maria de Jesus á Henriqueta, 21 Julho 1853, $2^{\circ}$ Ofício de Notas, Rio de Janeiro, Registro Geral, Livro 86 (03/05/1853-14/01/1854), AN-RJ, fl. 92v. (doravante, Carta de Liberdade, Henriqueta, 1853). 
nem as fontes incluem recibos. ${ }^{22}$ Entre os 83 vendedores que alugavam espaço na Praça do Mercado, em 1854, 53 vendiam peixe ou aves, competindo diretamente com Rufino e com mais dinheiro do que ele. $\mathrm{Na}$ sua própria rua, a Rua do Fogo, Henriqueta competia com outros dois vendedores, Antonio Francisco da Fonseca, um africano liberto vindo do Congo, especializado em verduras, e uma mulher brasileira, Maria Emília, que vendia somente quitandas em pequena escala. Dos 63 vendedores da sua vizinhança, em 1841, mais da metade era negra e dezesseis dos 27 africanos eram mulheres, embora, em geral, mais homens vendessem na rua do que mulheres. Somente vendedores com bancas permanentes eram identificados pelo endereço, tais como Maria Perpétua, de Benguela, que vendia hortaliças em sua casa, na Rua do Livramento, næ\% 58, onde seus clientes regulares sempre podiam encontrá1a. ${ }^{23}$ Vendedores que carregavam cestas, como Henriqueta, e que vagavam pelas ruas à procura de clientes, entendiam o trabalho como tão pesado quanto a duração do dia. Animosidades entre mulheres concorrentes provocavam divisões, que elas mesmas impunham e faziam valer, produzindo uma topografia social da cidade que destinou para as vendedoras escravas a área ao redor da igreja do Rosário e fez do Campo de Santana o lugar de venda das mulheres libertas. ${ }^{24}$

Esse processo enervante teria, em algum nível, relembrado o ritmo de trabalho que Rufino pudesse ter conhecido em solo iorubá? Provavelmente muito pouco. Embora alguns iorubás fossem comerciantes,

22 Divórcio, 1856, fls. 17 v.; Divórcio, 1857, traslado; Carlos Eugênio Líbano Soares, “A 'nação' da mercancia: condição feminina e as africanas da Costa da Mina, 1835-1900", in Juliana Barreto Farias, Carlos Eugênio Líbano Soares e Flávio dos Santos Gomes (orgs.), No labirinto das nações: africanos e identidades no Rio de Janeiro (Rio de Janeiro: Arquivo Nacional, 2005), pp. 210-2; Carlos Eugênio Líbano Soares, A capoeira escrava e outras tradições rebeldes no Rio de Janeiro, 1808-1850, Campinas: Editora da Unicamp, 2001, p. 107.

23 Almanak Laemmert, 1854, p. 504; Rellação Nominal das Cazas de Negocios da Freguesia de Santa Rita pertencente ao anno de 1841, "Estatística da Freguesia de Santa Rita", Arquivo Geral da Cidade do Rio de Janeiro (doravante, AGC-RJ), Códice 43-1-42 [s. p.].

${ }^{24}$ Corte de Apelação, Processo Crime n. 583, Amélia, mina, escrava de Domingos José Dias Guerreiro, acusada, Rio de Janeiro, 1854, AN-RJ, 1854, Maço 84, Gal. C, fls. 1, 2, 2v., 4, 5 v., 7, 8v., 10v., 15-16v., 17, 19, 39; Carlos Eugênio Líbano Soares comenta detalhadamente em "A 'nação' da mercancia”, pp. 210-2; Francisco Agenor de Noronha Santos, "Anotações de Noronha Santos a Introdução das 'Memórias", in Luiz Gonçalves dos Santos (Padre Perereca), Memórias para servir à história do Reino do Brasil, Belo Horizonte: Itatiaia, 1981; primeira edição de 1825, sobre Rosário, v.1, pp. 50, 62, 99-100. 
tecelões, fundidores de ferro, ferreiros, curtidores, surradores, entalhadores, alfaiates, músicos ou curandeiros, na sua maioria os homens eram lavradores - trabalho de homem, com as mulheres contribuindo somente nas colheitas mais exigentes. Porque a terra era abundante, ninguém a possuía, e simplesmente arrogava o direito de ocupá-la e cultivá-la. Uma área ficava com um homem até que ele a abandonasse e ela voltasse a ser terra comum. Já que os iorubás eram pessoas de vilas e pequenas cidades, um homem não vivia em sua terra, mas no vilarejo, com sua família, e todo dia andava até sua lavoura. Carneiros, bodes, gado, alguns porcos e galinhas eram mantidos dentro dos muros da vila. Com foice, machado e enxada, ele derrubava árvores e limpava a terra, plantava, cuidava da lavoura e colhia seus frutos. Produzia para as necessidades de sua família - milho, inhame, batata, feijão, amendoim, pimentão, abóbora, noz de cola, ervilha, café, vegetais de todos os tipos e algodão para tecer. ${ }^{25}$

Quão diferentes eram as propriedades que Rufino teria visto na Bahia, dedicadas à monocultura e cultivadas por escravos! Era um trabalho firmemente controlado, de longas jornadas e tarefas preestabelecidas, tipicamente realizado sob vigilância rigorosa, às vezes brutal, de um feitor. Embora roças algumas vezes fossem entregues para uso dos escravos, o que seria algo mais familiar a Rufino, ele provavelmente não chegou a cultivar uma horta. Essas roças, menos comuns na Bahia do que em outras regiões agrícolas, eram concedidas a escravos privilegiados (especialmente aos casados), uma posição que Rufino evidentemente nunca teria alcançado na Bahia, tanto que o senhor o vendera prontamente. ${ }^{26}$

25 Bowen, Central Africa, pp. 306-7; William H. Clarke, Travels and Explorations in Yorubaland, 1854-1858, Ibadan: Ibadan University Press, 1972, pp. 259-63; Samuel Johnson, The History of the Yorubas: From the Earliest Times to the Beginning of the British Protectorate, Londres: Routledge \& Kegan Paul, 1966; primeira edição de 1921, pp. 117-23; Richard Lander e John Lander, Journal of an Expedition to Explore the Course and Termination of The Niger with a Narrative of a Voyage down that River to its Termination, Nova York: Harper and Brothers, 1837, v. 1, p. 108; Smith, Kingdoms of the Yoruba, p. 125.

${ }^{26}$ Barickman, Bahian Counterpoint, 57-63; B. J. Barickman, “'A Bit of Land, which They Call Roça': Slave Provision Grounds on Sugar Plantations and Cane Farms in the Bahia Recôncavo, 1780-1860", HAHR, v. 74, n. 4 (1994), pp. 649-87; Francisco Peixoto de Lacerda Werneck, Memória sobre a fundação de uma fazenda na província do Rio de Janeiro, Rio de Janeiro: Laemmert, 1847, pp. 16-7; Hebe Maria Mattos, Das cores do silêncio: os significados da liberdade no sudeste escravista, Brasil, século XIX, Rio de Janeiro: Arquivo Nacional, 1995, pp. 151-3; Robert Slenes, Na senzala, uma flor: esperanças e recordações na formação da família escrava, Brasil sudeste, século XIX, Rio de Janeiro: Nova Fronteira, 1999, pp. 149-51, 187-97, 201, 237-53. 
Já Henriqueta poderia muito bem ter notado semelhanças entre suas vendas e o trabalho da mulher em uma vila iorubá. As mulheres iorubás, como os homens, se destacavam na manufatura. Elas cardavam e teciam algodão, tingiam pano de riscado azul e vermelho, extraíam azeite de dendê, fabricavam cerveja de milho, faziam jarros de barro e carregavam água, mas, principalmente, vendiam ou trocavam no mercado qualquer excedente, produzido pelos maridos, por outros suprimentos: tecido, sal, ferramentas e tintas corantes. Operavam numa rede de mercados que ia de pequenas vilas a grandes cidades - como o grande mercado de Ilorin, onde os comerciantes lidavam com algodão fino, cavalos árabes, espadas, sal e cativos - e que, ao fim e ao cabo, uniam o interior do território iorubá aos comerciantes árabes que viajavam em caravanas para o sul, desde as margens do Saara até o Sudão Central, canalizando mercadorias para a costa do Atlântico e, mais além, para portos europeus e americanos. ${ }^{27}$ Talvez Henriqueta entendesse de mercado por experiência própria ou, ainda garota, tivesse assistido sua mãe a trabalhar como uma das vigorosas mulheres que vendiam durante a semana em uma sequência de pequenas feiras, indo de cidade em cidade, transportando trouxas de mercadorias em suas cabeças pelas estradas empoeiradas, ou lamacentas na estação das chuvas, pagando uma taxa na entrada da cidade que lhes permitia vender. Em tempos de perigo, as mulheres formavam suas próprias caravanas, percorrendo longas distâncias, e sempre a pé. As esposas do rei - mulheres da realeza, "já passada a flor da vida," identificadas pelo tecido especial com que embrulhavam suas mercadorias e as isentavam dos impostos - também elas andavam de cidade em cidade a negociar. ${ }^{28}$ As mulheres dominavam o mercado local, eram os principais agentes comerciais, se não exclusivos, de suas vilas. Abaixo dos poderes políticos e sacerdotais

27 Clarke, Travels, pp. 263-8, 272-5; Johnson, History of the Yorubas, pp. 66, 123-5; Clapperton, Journal, pp. 14-5; Bowen, Central Africa, p. 224, 297; Smith, Kingdoms of the Yoruba, pp. 6-7, 157; Lander e Lander, The Niger, v. 1, p. 86, 108; T. J. Bowen, Grammar and Dictionary of the Yoruba Language, Smithsonian Contributions to Knowledge, Washington: Smithsonian Institution, 1858, pp. x-xi.

28 Johnson, History of the Yorubas, p. 66, 245; Lander e Lander, The Niger, v. 1, pp. 121-22 ; Clarke, Travels, pp. 13, 33-4, 45, 54, 184; Clapperton, Journal, p. 21; La Ray Denzer, "Yoruba Women: A Historiographical Study", International Journal of African Historical Studies, v. 27, n. 1 (1994), pp. 6,7, 8-13. 
exercidos por mulheres de alto escalão, em cada cidade uma mulher supervisionava a administração do mercado. ${ }^{29}$ Mulheres podiam adquirir autoridade, independência e riqueza como comerciantes e exercer um reconhecido poder.

Enquanto Henriqueta descobria que o trabalho de venda nas ruas do Rio de Janeiro era diurno, com sinos da igreja e toques de recolher a chamar as pessoas de volta para casa ao escurecer - pois mulheres andando sozinhas à noite arriscavam suas reputações - os mercados iorubás eram pontos de encontro noturnos saboreados tanto para a sociabilidade, quanto para o comércio. Ao pôr-do-sol, "todos os tipos de pessoas, homens, mulheres, meninas, viajantes recém-chegados em caravanas, agricultores vindos dos campos e artesãos de suas casas" invadiam o mercado para "comprar, vender e conversar". Alguns se sentavam agrupados ao redor de uma fogueira, enquanto outros formavam pequenas ilhas de luz na escuridão com seus candeeiros. Já às dez horas o "cantarolar e murmurar" das vozes de mulheres era ouvido e suas gargalhadas flutuavam na noite. Contudo, a camaradagem dificilmente enfraquecia o talento de comerciantes astutas, que lançavam mão de todos os "pequenos truques" na condução de uma difícil barganha. ${ }^{30}$

Elas trouxeram seu comportamento vivaz para o Brasil, onde os senhores de escravos achavam que as mulheres minas eram domésticas ruins, porque altivas e independentes, e não dóceis o bastante. Eram melhores como ganhadeiras de rua. ${ }^{31}$ Elas representavam, para Henriqueta, modelos de trabalho feminino que vinham de uma tradição de mulheres iorubás fortes.

Mas quanto Rufino e Henriqueta sabiam das lavouras e dos mercados africanos em tempos prósperos e pacíficos? Até o fim da década

29 Johnson, History of the Yorubas, p. 66; Lander e Lander, The Niger, v. 1, pp. 121-22; John Iliffe, Honour in African History, Cambridge: Cambridge University Press, 2005, p. 80.

30 Bowen, Central Africa, pp. 97-8, 297, 296 (citação); Clarke, Travels, pp. 264, 272-275, 267 (citação); Lander e Lander, The Niger, v.1, pp. 86, 170-171, 121, 123, 142, 160 (citação); Clapperton, Journal, p. 12.

31 Lander e Lander, The Niger, v. 1, p. 121; Johnson, History of the Yorubas, p. 101, 245; Louis e Elizabeth Agassiz, A Journey in Brazil (1868), Nova York: Praeger, 1969, pp. 82-5; Daniel P. Kidder e James C. Fletcher, Brazil and the Brazilians, Portrayed in Historical and Descriptive Sketches, Philadelphia: Childs e Peterson, 1857, pp. 135-6; Bowen, Central Africa, pp. 303-4. 
de 1820, os desgastes da guerra - vilas em ruína, pessoas fugindo para cidades maiores em busca de segurança - desenraizaram os padrões comuns da vida cotidiana e espalharam a agitação em que dezenas de milhares de iorubás foram capturados. Em meados da década 1820, Hugh Clapperton e Richard Lander, os primeiros europeus a escreverem sobre região iorubá, notaram a paz e a produtividade dos lugares pelos quais passavam. No entanto, numa viagem de volta com seu irmão, alguns anos mais tarde, em 1830, Lander encontrou condições tristemente deterioradas. Nos anos 1850, um missionário americano descreveu cidades iorubás "desoladas" e "despovoadas", dilaceradas, primeiramente, pela guerra civil e, depois, pelo comércio de escravos. ${ }^{32}$ Apesar disso, a guerra teria passado por alguns lugares deixando-os intactos, ou ainda capazes de se recuperar mais rapidamente. Talvez Henriqueta e Rufino pertencessem a uma dessas poucas vilas, embora sua venda para fora do território iorubá não sugira isso.

\section{Entre iguais}

Já libertos Henriqueta e Rufino viviam no Rio de Janeiro na freguesia de Santa Rita, uma parte antiga da cidade ao lado da extensa Baía de Guanabara. O morro de São Bento e o mosteiro dos beneditinos ofereciam paisagens magníficas da baía e das colinas de granito cobertas pela floresta tropical. O morro da Conceição separava as ruas internas da praia do Valongo, com seus cais e armazéns, que recebiam navios de longo curso principalmente para dali levar o café exportado para fora do país. A Praça Municipal, próxima ao cais e ao prédio da alfândega, junto com o mercado central da cidade, ligava a vida daquela freguesia ao mar e ao comércio. A capela de Santa Rita, construída em 1721 cinco altares laterais assinalavam sua importância - tornou-se igreja matriz da freguesia em 1753, quando Santa Rita foi separada da freguesia de Nossa Senhora da Candelária. Uma fonte construída em frente à igreja fornecia água limpa para os paroquianos desde 1840, apenas pou-

32 Clapperton, Journal, para os anos 1825 e 1827, passim; Lander e Lander, The Niger, v. 1 (a viagem dele começou em 1830); Smith, Kingdoms of the Yoruba, p. 102, 166; Bowen, Central Africa, pp. 113-4. 
cos anos antes de Henriqueta e Rufino começarem suas vidas na vizinhança. No século XIX, a freguesia se tornou lugar cosmopolita para o comércio e despacho marítimo.

Henriqueta e Rufino se adaptaram bem. Como o resto da cidade, Santa Rita era impressionantemente africana em 1849, e Henriqueta, ainda escravizada, era uma das 3.082 mulheres africanas do Rio de Janeiro, e Rufino um dos 7.135 homens africanos. Os africanos representavam $29 \%$ da população total do Rio e quase um terço da população da freguesia. Aqui nossos personagens viviam não somente entre angolanos, congoleses, moçambicanos, mas também entre os seus iguais outros minas.

Pistas dos minas aparecem em suas associações e redes de amizade. Rufino tomou emprestado, em data desconhecida, 100 mil réis, a juros de $3 \%$ ao mês, de um "preto mina", identificando-o respeitosamente como "senhor Guilherme". Os acontecimentos da sua casa eram conhecidos e comentados por outros minas, de acordo com Cândido de Paulo Menezes, um marinheiro brasileiro, casado, de 26 anos, cujos pais pertenciam a esta nação. Ele conhecia os minas que frequentemente se juntavam na casa de Henriqueta e Rufino. Cândido, sem nenhuma experiência africana própria, mantinha contato com os minas através de seus pais. A herança cultural de pessoas como ele normalmente estaria perdida para nós, porque identificadas meramente como "brasileiras", com suas conexões africanas apagadas, mas, por causa da eventualidade de seu testemunho, encontramos a segunda geração, um homem nascido no Brasil com raízes minas que ele, evidentemente, valorizou e manteve. ${ }^{33}$

Mas as relações sociais cotidianas que Henriqueta e Rufino mantinham estavam longe de serem exclusivamente com outros minas. Havia uma mulher analfabeta de Luanda, Domingas Maria da Conceição, que se sustentava lavando roupas e que viveu com eles durante meses, e uma jovem costureira, nascida no Brasil, que alugou um quarto na casa

33 Noronha Santos, “Anotações", sobre Santa Rita, v. 1, pp. 135-6. A população africana total no Rio em 1849 era de 52.341, Recenseamento do Rio de Janeiro, 1849, Mapa 4, Santa Rita, e Mapa 9, Freguesias da Cidade; Inventário, 1858, fls. 5, 8; Divórcio, 1856, fls. 37v.-8v. 
deles logo depois que se casaram. Quando possível, o casal conseguia cobrir metade do próprio aluguel sublocando quartos. Durante algum tempo, Henriqueta pensou em comprar uma escrava para ela, algo comum entre pessoas libertas, já que a propriedade em escravos estava difundida em todas as classes. É quase certo que as escravas que ela inspecionava, trazidas à sua casa por algum negociante para saber se a agradavam, eram angolas ou congos, que excediam em dez ou mais vezes o número dos minas no Rio de Janeiro, tornando pequenas as suas chances de encontrar uma escrava mina. O casal também tinha como amigos o comerciante Antonio Godinho, brasileiro alfabetizado, natural de uma província vizinha, e sua esposa. Antonio narrou que os dois casais frequentemente se "visitaram mutuamente". ${ }^{34}$

Como seus amigos íntimos, porém, eles escolheram dois outros minas que tinham se libertado algum tempo antes dessa história começar. Joaquina Mathildes do Espírito Santo e seu marido, Venancio Francisco dos Santos, aparecem nos documentos como casal um pouco mais velho, mais experiente e assentado do que Henriqueta e Rufino, uma história transatlântica de sucesso para ser tomada como exemplo. Henriqueta e Rufino os convidaram para testemunhas de seu casamento, embora, estranhamente, o nome de Joaquina não apareça na certidão de casamento e somente a assinatura de Venancio esteja presente (escrita trêmula, sugerindo que ele se esforçou para assinar o nome e que era, no máximo, pouco alfabetizado), junto com outra assinatura, de outra testemunha do sexo masculino. Nos documentos desse caso, Henriqueta frequentemente se referia a Joaquina como sua "madrinha", significando não uma madrinha de batismo, mas uma confidente, alguém em quem confiava. Joaquina e Venancio eram pobres, mas, juntando as rendas dele como trabalhador no Arsenal de Guerra e os ganhos dela da venda de quitanda, mais o ganho dos seus escravos, que trabalhavam por conta própria, eles viviam decentemente na Rua do Cano, no centro da cidade, apenas a dois quarteirões de Henriqueta e Rufino. Não era uma amizade simplesmente por conveniência, de vizinhos que casualmente se encontravam e conversavam na rua. No primeiro ano do casa-

${ }^{34}$ Divórcio, 1856, fls. 13-13v., 35-6v.; Justificação, 1856, fls. 3-3v., 13v., 19; Inventário, 1858, fl. 12 . 
mento de Henriqueta e Rufino, provavelmente em outubro de 1855, Joaquina e Venancio lhes emprestaram quase um mês de suas rendas para pagar a fiança e tirar Rufino da cadeia. ${ }^{35} \mathrm{E}$ eles teriam importância central e dramática para o casal, com o desdobramento do divórcio.

Em termos de "representação do eu", ser mina era importante. ${ }^{36}$ Rufino usava no rosto marcas identificadoras da sua terra natal. Pois aos seis ou sete anos de idade, as escarificações que anunciavam seu pertencimento a um grupo étnico ou linhagem iorubá eram feitas com uma ferramenta de metal afiada, por um sacerdote hábil na arte do trabalho com metal e que invocava a divindade Ogum. Era exigida uma força notável, publicamente atestada, para suportar em silêncio os cortes, e sua realização valia como um tipo menor de iniciação, um ensaio para a circuncisão. ${ }^{37} \mathrm{Um}$ menino de Oyó podia usar três linhas horizontais ou verticais curtas em cada bochecha, os homens do reino de Owu podiam ter três marcas verticais sobre três horizontais e os yagba, outro subgrupo iorubá, usavam três marcas, começando em um ponto no canto da boca e se espalhando na direção da bochecha, enquanto ainda outros usavam uma única cicatriz vertical, ou três paralelas, embaixo de cada olho. As variações eram muitas e, algumas vezes, complexas. Qualquer um que reconhecesse os padrões poderia distinguir um grupo do outro, e guerreiros, estando perto, distinguiam um aliado de um inimigo. As mulheres e as meninas também usavam desenhos em seus corpos, como "muitas mulheres de Bídjie [uma vila pouco distante do norte de Badagri]", que, em 1830, dois viajantes ingleses observaram,

35 Casamentos, Freguezia de Santa Rita, Livro 5 (1852-1860), ACM-RJ, AP552, fl. 41; Divórcio, 1857, traslado; Justificação, 1856, fls. 2v, 4-4v.; Divórcio, 1856, fls. 10, 16, 43; Inventário, 1858, fl. 10. As fontes não indicam porque Rufino estava preso nesta ocasião.

36 A frase pertence a Erving Goffman, Presentation of Self in Everyday Life, Garden City: Double Day, 1959.

37 Henry John Drewal, "Art or Accident: Yorùbá Body Artists and their Deity Ògún”, in Sandra T. Barnes (ed.), Africa's Ogun, Old World and New (Bloomington: Indiana University Press, 1989), pp. 235-60; Eugenia W. Herbert, Iron, Gender, and Power: Rituals of Transformation in African Societies, Bloomington: Indiana University Press, 1993, p. 213, 25, 34, 40, 123, 233; Ilifee, Honour in African History, pp. 101-3; P. C. Lloyd, "Osifekunde of Ijebu", in Philip D. Curtin (ed.), Africa Remembered: Narratives by West Africans from the Era of the Slave Trade (Madison: University of Wisconsin, 1967), pp. 255-8; Ifi Amadiume, Male Daughters, Female Husbands: Gender and Sex in an African Society, Londres: Zed Books, 1987, p. 28; Michael A. Gomez, Exchanging Our Country Marks: The Transformation of African Identities in the Colonial and Antebellum South, Chapel Hill: University of North Carolina Press, 1998, p. 131. 
com desaprovação, como tendo "a carne de suas testas em relevo na forma de bolas de gude e suas bochechas similarmente cortadas e deformadas". A família real de Oyó reservou para si as "marcas de fitas largas [...] desenhadas ao longo de todo o comprimento das pernas e dos braços". Apesar de os outros minas poderem ler as marcas do rosto de Rufino, o escrivão do processo de divórcio as descreveu somente como os "sinais da sua Nação", não vendo motivo para perguntar de que grupo eram ou para descrevê-las em detalhes reconhecíveis e, sendo assim, a origem precisa de Rufino se perdeu para nós. Não ficou perdido, porém, o fato indelével do seu pertencimento. As marcas tribais para sempre o identificariam como sendo "da Nação mina". ${ }^{38}$

Henriqueta anunciou seu passado mina de outra maneira. Como centenas de mulheres minas, ela continuou a usar a tradicional tira de pano de algodão, chamado pano da costa, confeccionado em território iorubá e exportado para o Brasil em milhares de peças a cada ano. As mulheres iorubás da África tipicamente se enrolavam com duas tiras de pano, com uma terceira cruzando seus ombros, enquanto no Brasil o pano da costa se tornaria um xale. Um comerciante do Rio de Janeiro, do Largo de São Joaquim, não muito longe do bairro de Henriqueta, lembrou da visita de Henriqueta a sua loja para pegar o pano da costa que ela havia encomendado. Decidindo usá-lo logo, ela o jogou em volta dos ombros e saiu para a rua. Uma orgulhosa exibição de ser mina.

Tão impressionante era a presença de mulheres minas no Rio de Janeiro por volta de 1836 que a figura da comerciante mina se tinha tornado um tipo social reconhecido e assim permaneceu até a década de 1860, quando Elizabeth Agassiz ali as achou encantadoras. Os minas, ela escreveu,

são uma raça de aparência poderosa e as mulheres, especialmente, são bem-feitas e têm uma presença digna [...] A negra mina é quase invari-

38 Johnson, History of the Yorubas, pp. 104-7; Lloyd, "Osifekunde of Ijebu", pp. 255-258; Reis, Rebelião Escrava, pp. 311-5; Reis e Mamigonian, "Nagô and mina", pp. 82-3; Smith, Kingdoms of the Yoruba, p. 146; C[hristopher] G[belokoto] Okojie, Ishan Native Laws and Customs, Yaba: John Okwesa \& Co., 1960, p. 45; Lander e Lander, The Niger, v. 1, p. 94; Jean Baptiste Debret, Voyage pittoresque et historique au Brésil, ou séjour d'un artiste français au Brésil, Paris: Firmin Didot Frères, 1835, $2^{\mathrm{e}}$ Partie, Planche 22, "Esclaves Nègres de Différentes Nations", e o texto 77; Divórcio, 1856, fl. 43. 


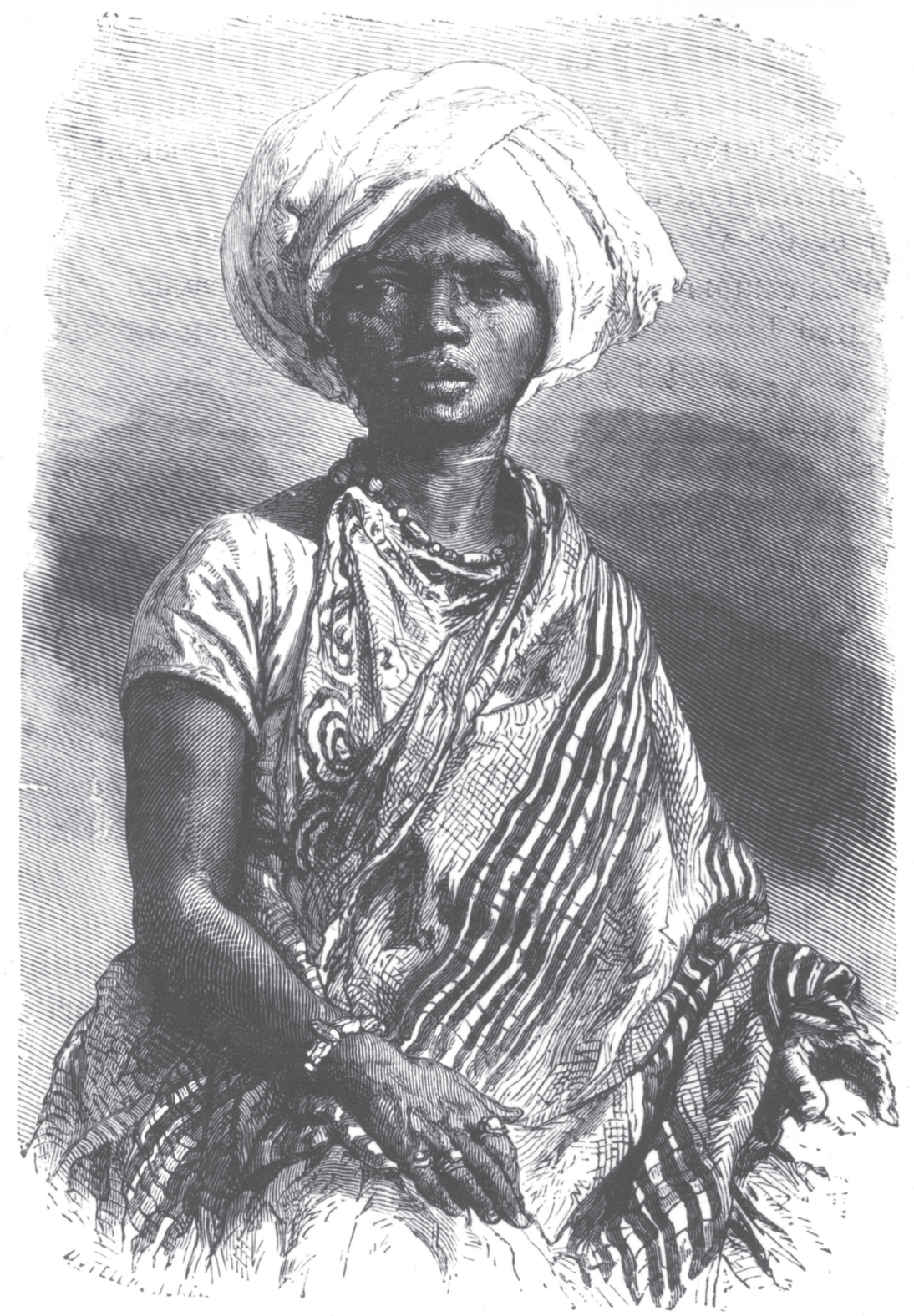

Uma mina com pano da costa

Fonte: Onésime Reclus, A Bird's-eye View of the World. A Popular Scientific Description of the Great Natural Divisions of the Globe, Boston: Ticknor, 1892, p. 797. 
avelmente notável por suas lindas mãos e braços. Ela parece ser consciente disso e, geralmente, usa pulseiras justas nos punhos [...].

Suas palavras lembram as de um inglês na África que, nos anos 1820, viu "imponência" no modo de as mulheres iorubás andarem e se arrumarem, e, apesar dos pesados fardos que carregavam, terem uma "aparência graciosa e atraente". E as palavras deles ecoam a própria descrição feita por Rufino de sua esposa, como uma "preta bonita e de elegante estatura". 39

Quando Henriqueta se vestia para sair, qual, exatamente, era sua preparação? O padrão de beleza feminina dela teria vindo de seu passado iorubá, aquele que ela trouxe do outro lado do Atlântico, ou do que aprendeu no Brasil com outras mulheres mina-iorubás? Ela trançaria seu cabelo, como as mulheres iorubás casadas o faziam, em fileiras nítidas dos lados para o centro da cabeça ou da testa para a parte de trás da cabeça, ou ela colocaria uma rede sobre o cabelo, decorada com cordões de contas de corais, penduradas da coroa para a testa? Ela escovaria seus dentes, até obter uma brancura brilhante, com as raízes fibrosas de certo arbusto ou árvore? Ela aplicaria lustre às suas já escuras pálpebras, pintando-as com kohl, um pó preto azulado? Ela usaria as joias que Rufino disse que lhe dera e, talvez, seu valioso cordão de ouro? Seu pescoço, seus punhos e dedos brilhavam com os braceletes e anéis ao estilo das mulheres da realeza iorubá?

Para terminar de se arrumar, o que ela usava nos pés? Essa não é uma pergunta simples. Escravos no Brasil, sendo-lhes negados sapatos, iam descalços a toda parte e em qualquer clima, e os sapatos, quando usados por negros pobres, tornavam-se símbolos de liberdade. Contudo, um missionário batista, William H. Clarke, que visitou o território iorubá nos anos 1850, relatou que os homens iorubás (ele não mencionou as mulheres) raramente usavam sandálias, exceto quando estavam viajando. ${ }^{40}$

39 Justificação, 1856, fl. 19; Bowen, Central Africa, 299; Carlos Eugênio Líbano Soares, "A 'nação' da mercancia", pp. 224-25; Agassiz, A Journey in Brazil, pp. 82-5, 83 (desenho); Lander e Lander, The Niger, v. 1, p. 109, 121; Divórcio, 1856, fls. 9-10; Divórcio, 1857, traslado.

40 Lander e Lander, The Niger, v. 1, p. 73-4 e v. 2, pp. 240-2; Johnson, History of the Yorubas, p. 101; Bowen, Central Africa, p. 300; Clarke, Travels, pp. 243-44; Thornton, sobre mulheres que usavam turbantes, Africa and Africans, p. 233. 
Os escravos minas do Brasil davam de ombros e nem ligavam para seus pés descalços ou a humilhação os golpeava? Minha opinião é que, aqui, o estilo brasileiro teria vencido o iorubá e a orgulhosa Henriqueta, como uma mulher já liberta, saía de sandálias.

Aonde ela ia? Como mina, ela qualificava-se para participar de uma das irmandades leigas católicas que se tinham tornado expressão das afinidades e das animosidades africanas. No Rio de Janeiro do século XVIII, os minas estabeleceram uma irmandade dedicada aos santos negros Elesbão e Efigênia e, embora admitissem mulheres e as considerassem aptas para servir no conselho da administração, incisivamente barravam as "pretas de Angola", assim como crioulas e mulheres mestiças - presumivelmente descendentes de angolanos que ainda eram vistas como angolanas - de exercer qualquer função. Os minas, de longe a menor nação africana no Rio de Janeiro, tinham unido resistência secular à devoção, reduzindo o poder das numerosas angolas, mas acolhendo as mulheres de Moçambique, São Tomé e Cabo Verde. Os angolas, por sua vez, tinham fundado sua própria confraria em Nossa Senhora de Belém e controlavam a administração da irmandade de Nossa Senhora do Rosário. A devoção tornou-se territorial e refletiu-se em conflitos duradouros (lembrando que o conflito em si é uma "forma de associação humana") entre africanos que apresentavam diferenças culturais e linguísticas, trazidas de um lugar distante e transformadas em jogos de poder que aconteciam nas irmandade no aqui e agora. ${ }^{41}$

Ou talvez Henriqueta e sua amiga mina Joaquina voltassem para casa tarde depois de assistir a uma cerimônia de candomblé. Africano na origem, e transformado de acordo com as circunstâncias baianas, o candomblé veio para o Rio de Janeiro com as migrações iorubás da Bahia, especialmente depois da Revolta dos Malês, em 1835. Dançar

${ }^{41}$ Compromisso da Irmandade dos Santos Elesbão e Ephigenia desta Corte do Rio de Janeiro, o qual foi feito em 1740 [panfleto], Rio de Janeiro: [s. ed.], 1917, pp. 3, 10-1, 14, ACM-RJ, Associações Religiosas, n. 198; Mariza de Carvalho Soares, Devotos da cor: identidade étnica, religiosidade e escravidão no Rio de Janeiro, século XVIII, Rio de Janeiro: Civilização Brasileira, 2000, pp. 180-9; Karasch, Slave Life, pp. 82-5; Mariza de Carvalho Soares, "O império de Santo Elesbão na cidade do Rio de Janeiro, no século XVIII", Topoi, n. 4 (2002), pp. 59-83; sobre conflito, Hagith Sivan, Palestine in Late Antiquity, Nova York: Oxford University Press, 2008, p. 10. 
era essencial para os rituais realizados em devoção aos orixás, entidades complexas e de múltiplos aspectos que, ao mesmo tempo, representam a energia da vida, as forças da natureza, tais como os raios, e ancestrais sagrados. Iniciadas, as filhas de santo, típica mas não exclusivamente mulheres, entoavam cânticos e circulavam na sala enquanto os tambores "trovejavam no ar", até que um orixá "descia" e uma dançarina girava para fora da roda, balançando-se e em transe, cercada por assistentes protetores que folgavam uma faixa ou um turbante apertado ou evitavam sua queda. ${ }^{42}$

É mais provável que os encontros que Rufino a acusava de frequentar e depreciava como decadentes eram nada mais do que diversão, danças - o batuque ou lundu - trazidas pelos escravos de Angola e do Congo para o Brasil. A exuberância do movimento, da música e dos tambores atraía os africanos e, de forma crescente no século XIX, crioulos e brancos, para as ruas e praias nas noites de sábado e dias santos. ${ }^{43}$ Nessas ocasiões comemorativas, Henriqueta provavelmente não era a única a se arrumar.

\section{Expectativas morais}

Tendo feito tanto esforço para se casar na Igreja, Henriqueta não se afastou simplesmente do seu casamento, mas atentou para as regras de um "divórcio", o termo usado nos documentos, mas que, mais precisamente, descrevia uma separação que não dissolvia o matrimônio, coisa que somente a anulação, sob circunstâncias especiais, poderia fazê-lo. Nenhum dos dois poderia casar novamente enquanto o outro vivesse, mas poderiam viver separados e buscar a divisão de seus bens no tribunal civil, como Henriqueta e Rufino o fizeram. ${ }^{44}$ Ela acusava Rufino de

${ }^{42}$ Rachel E. Harding, A Refuge in Thunder: Candomblé and Alternative Spaces of Blackness, Bloomington: Indiana University Press, 2000, capítulos 5-8, p. 90 (citação baseada em fonte de 1866); João José Reis, "Candomblé in Nineteenth-Century Bahia: Priests, Followers, Clients", Slavery and Abolition, v. 22, n. 1 (2000), pp. 116-34; e João José Reis, Domingos Sodré, um sacerdote africano: escravidão, liberdade e candomblé na Bahia do século XIX, São Paulo: Companhia das Letras, 2008.

43 Karasch, Slave Life, pp. 241-245.

${ }^{44}$ Constituições primeiras do Arcebispado da Bahia. Feitas e ordenadas por D. Sebastião Monteiro da Vide, $5^{\circ}$ Arcebispo do dito Arcebispado do Conselho de Sua Magestade: Propostas e 
violência física "atroz", tão severa que, se tivesse continuado, a vida dela correria perigo. Algumas vezes, ela fugia para a casa da madrinha para escapar das "garras" dele. Testemunhas disseram que tinham visto a "ferocidade" de Rufino, "ferimentos, contusões", e Henriqueta com seu "rosto todo ensanguentado". Ela descreveu os ataques dele como se brotassem de um "gênio atrabiliário e irascível". Rufino, previsível e indiferentemente, negou tê-la machucado e não ofereceu detalhes. Ninguém achou seu depoimento convincente e o processo prosseguiu. ${ }^{45}$

Feitas as alegações formais, brigaram pelo que realmente importava para eles: trabalho, dinheiro, débitos. Ambos se preocupavam com respeitabilidade e reputação, e cada um tinha suas próprias ideias sobre como resolver as coisas. Ao apresentar versões divergentes do que havia acontecido, revelavam suas expectativas de como a vida de casal deveria ser conduzida: uma mistura de comportamento honrado e responsabilidades compartilhadas, adaptada às circunstâncias. Cada um acusava o outro de trair esse código. ${ }^{46}$

No final, chegou-se ao que seria justo, aquilo que Rufino chamou de "lei de branco" ao falar das regras que regem a propriedade conjugal no Brasil. Na sua versão, metade de tudo que ela tinha pertencia a ele. Ele assim se colocou: "Você tem quatro vinténs, dous são de seu marido; você tem um lenço, há de parti-lo no meio, dando a metade a seu marido". ${ }^{47}$ Quando ela respondeu que ele também deveria trabalhar e metade do dinheiro ganho por ele deveria ir para ela "para que a lei de branco pudesse observar-se justamente", ele bateu nela. Sempre que ela vinha para casa com dinheiro, ele imediatamente pegava a metade e ela ficava com o restante para pagar todas as despesas comuns.

aceitas em o synodo diocesano que o dito Senhor celebrou em 12 de junho do anno de 1707. Impressas em Lisboa no anno de 1719 e em Coimbra em 1720, São Paulo: Typ. "2 de Dezembro", 1853, Liv. 1, Tít. 72, nos. 305-17 (doravante, Constituições primeiras, 1853).

45 Divórcio, 1856, fls. 15v.-6, 35-8v.,41-2, 45v.; Justificação, 1856, fls. 4v., 22-3v.

46 Aqui e nos parágrafos seguintes, o material entre aspas é do Divórcio, 1857, transcrito, s.p.

47 Candido Mendes de Almeida (comp. e ed.), Código Philippino: ou Ordenações e leis do reino de Portugal, recopiladas por mandado d'el-rey D. Philippe I. 14 ed. segundo a primeira de 1603 e a nona de Coimbra de 1824, adicionada com diversas notas, Rio de Janeiro: Typ. do Instituto Philomathico, 1870 (doravante, Código Philippino, 1870), Liv. 4, Títs. 46, parágrafo. $1^{\circ}, 82,96$; para as exceções de quando as propriedades estiverem completa ou parcialmente separadas por contratos pré-nupciais, ver Liv. 4, Títs. 46, 47; Divórcio, 1856, fl. 17. 
Segundo ela, ele não lhe dava nenhum dinheiro do aluguel coletado de seus inquilinos, e também não o gastava com nada de uso mútuo. De uma gaveta que ela mantinha trancada, ele furtara sua estimada corrente de ouro. Ela sozinha ganhava o dinheiro que sustentava os dois, até mesmo o aluguel, enquanto ele ficava "só deitado ou a vadiar pelas ruas". Quando ela reclamava, ele lhe dizia que era "muito desaforo querer a mulher governar o marido e atrever-se a repreendê-lo". O desprezo dela por ele era indisfarçável: ele se recusava a trabalhar e não tinha nada de seu, tornando "irrisória" a ideia de que ele a sustentava.

Rufino defendia a si mesmo dizendo que, com seus ganhos, ele cuidava de Henriqueta, desde as necessidades cotidianas às joias e visitas de médico. Insistia em que ela trabalhava porque estava acostumada a se ocupar de vender na rua e, quando casaram, não querendo "contrariar o seu gênio", permitiu que ela continuasse a trabalhar, mas o que ela ganhava era dela, para suas roupas e diversões, nunca para pagar as contas da casa ou o aluguel. Embora, mais tarde, testemunhas e um inventário da propriedade que possuíam desacreditassem as afirmações de Rufino, ele se agarrava a essa noção padrão de dignidade masculina, descrevendo a si próprio como um marido dedicado e provedor.

Suas dívidas alimentaram a briga. Ela o acusou de consumir o lucro da venda do peixe sem lhe dar um centavo, deixando-a pagar sozinha as dívidas contraídas. Ele respondeu que sempre que ela perdia dinheiro, ele cobria suas dívidas com os fornecedores. Nada exprimia mais o rancor dela do que a questão da liberdade de Rufino. O registro mostra claramente que Henriqueta comprou a sua liberdade de sua dona, Rosa Maria de Jesus, pagando em dinheiro a pesada quantia de 1:300\$000 (um conto e trezentos mil reis), conforme observado em sua carta de alforria, ditada por uma Rosa Maria, analfabeta, e devidamente registrada por um tabelião em julho de $1853 .{ }^{48}$ A liberdade de Rufino virou controvérsia porque ela afirmou ter pago por ela 1:400\$000 (um conto e quatrocentos mil reis), o preço de mercado de um escravo homem sem doença, em idade produtiva. Esse valor foi, claramente, mui-

48 Divórcio, 1856, fl. 17v.; Divórcio, 1857, traslado; Carlos Eugênio Líbano Soares, "A 'nação' da mercancia", pp. 210-2; Carlos Eugênio Líbano Soares, Capoeira escrava, p. 107; Carta de Liberdade, Henriqueta, 1853. 
to além de suas economias, e ela tomara emprestado quase um terço ao major João Francisco de Albuquerque Câmara, a quem evidentemente pagou porque tal quantia não estava incluída entre as outras dívidas que pagaria mais tarde. Ela afirmou ter valido a pena fazer o pagamento, dizendo que tinha agido em obediência "aos impulsos de seu coração", para que eles pudessem casar "em legítimas núpcias" perante um padre em missa solene. ${ }^{49}$ Ele insistiu que tinha economizado o dinheiro para comprar sua própria alforria, mas tinha entregue o dinheiro a Henriqueta para ela fazer o pagamento porque, como escravo, ele temia ter dinheiro em seu poder. Poderiam suspeitar de que o havia roubado ou seu senhor poderia recusar-se a reconhecer seu direito ao pecúlio ou, ainda, poderia roubá-lo. Muitos escravos deixavam seu pecúlio com uma pessoa liberta, de confiança, para guardá-lo com segurança ${ }^{50}$ Era uma estratégia plausível.

Henriqueta via isso de forma diferente. Rufino trabalhava no ganho. Antes de pagar por sua alforria, ela frequentemente complementava o jornal que Rufino devia a Warleta, quando ele não conseguia ganhar o suficiente. Era uma quantia alta para um escravo que trabalhava no ganho, nos anos 1850, e um fardo pesado para ela. Mas, para que ele não fosse chicoteado, ela dizia que pagava o saldo, e às vezes o dinheiro de uma semana inteira. Se ele não conseguia ganhar nem aquela quantia, como, perguntou ela, poderia ter comprado sua própria liberdade? Era uma imagem negativa dele como parceiro moroso numa relação que, pela lei de branco, deveria ser igualitária.

No final, não havia propriedade, somente dívida. Pela lei, as dívidas, assim como os bens, eram do casal conjuntamente, e as deste totalizavam uma quantia desanimadora. Na verdade, Rufino tinha acumulado todos os débitos, mas, vendo ela que "os credores continuamente

49 Para os preços, ver Pedro Carvalho de Mello, "The Economics of Labor in Brazilian Coffee Plantations, 1850-1888", artigo apresentado ao Departmento de Economia da Universidade de Chicago, Nov. 1974, p. 16 (Figura II); para taxas de trabalho no ganho, ver p. 30 (Figura VIII); é estranho que a carta de alforria de Rufino não registre a quantia paga, Carta de Liberdade, Rufino, 1854; Divórcio, 1856, fl. 3; Divórcio, 1857, traslado; Inventário, 1858, fl. 5.

50 Somente com a Lei de Rio Branco, de 1871, foi legalmente permitido a um escravo possuir pecúlio, mas a ela não garantia sua segurança, ver Leis, estatutos etc., Coleção das Leis do Brasil, Lei 2040, 28 Sept. 1871, Art. 4; Divórcio, 1856, fl. 9. 
importunavam a ela pelo pagamento", colocando sua reputação em risco, ela já tinha pago tudo. A justiça ordenou que Rufino reembolsasse Henriqueta da sua metade dos débitos restantes e dos custos do processo na Justiça, mas tudo que ele tinha era um dinheiro emprestado, parte do débito. Mais de um ano depois, ela ainda aguardava receber. ${ }^{51}$

Após tudo terminado, o que eles ganharam? Rufino acabou mal. Dentro e fora da cadeia, por fraude e roubo, ele minava decisivamente seu próprio terreno, fazendo seu advogado desistir e, silenciosamente, o caso definhar. ${ }^{52}$ Rufino queria o controle sobre sua esposa restaurado, mas isso não aconteceu. Ele parecia alquebrado com a ausência dela.

Henriqueta conseguiu um fim para o acúmulo de dívidas e a libertação de um casamento que tinha afundado na violência. Contudo, havia algo mais. A fim de restaurar seu bom nome, como uma pessoa que ganhava a vida honestamente e pagava suas dívidas, tendo em mente que um nome limpo era seu melhor crédito, ela teve que reconquistar a confiança da praça, que não era algo a ser conseguido automaticamente, mas "gerado, comunicado e negociado". ${ }^{33}$ Henriqueta precisava encontrar uma maneira de se distanciar publicamente de seu marido, e a Justiça ofereceu uma solução persuasiva. Ao longo do século XIX, processos iniciados por gente pobre enchiam os tribunais do Rio de Janeiro. Quem era a plateia para esses grossos maços de papel escritos numa língua distante, muito diferente da língua da rua? Quem saberia que Henriqueta tinha ganho as assinaturas de aprovação de juízes eclesiásticos ou a contabilidade detalhada dos bens feita por um juiz civil? Suspeito que a resposta seja quase todo mundo - todo mundo que importava nos encontros se sua vida, especialmente sua amiga Joaquina, a sua locatária e, certamente, aqueles que fizeram empréstimos a seu marido. Os fornecedores e os clientes regulares de Henriqueta saberiam logo do divórcio. Na rua, onde quase nada passava despercebido, seu êxito nos tribunais seria comentado e sua reputação - como mulher que fazia

51 João José Reis, “A greve negra de 1857 na Bahia”, Revista USP, n. 18 (1993), pp. 7-29; Inventário, 1858, fls. 4v.-5, 6, 8, 21-23, 25; Divórcio, 1856, fls. 15, 17v.

52 Divórcio, 1856, fls. 41-3.

${ }^{53}$ Craig Muldrew, The Economy of Obligation: The Culture of Credit and Social Relations in Early Modern England, Nova York: St. Martin's Press, 1998, p. 151. 
negócio por sua própria conta e que levava a vida honradamente - seria falada, e seus esforços recompensados. Antes de 1861, já tinha conseguido licenças para, não apenas uma, mas duas barracas no Largo do Rosário, e as estava renovando. Se Rufino foi despojado do seu "direito ao orgulho", Henriqueta recuperaria o dela. ${ }^{54}$

\section{A lei iorubá}

Toda a troca de palavras entre Henriqueta e Rufino sobre a "lei de branco" sugere a sua contrapartida, uma lógica africana, um código alternativo não escrito, mas oralmente transmitido sobre a conduta do casamento e do divórcio, a lei iorubá. Eles já conheciam as leis brasileiras, mas qual parte da lei iorubá ainda funcionava nessa causa? Estava esquecida, deixada para trás, nunca usada? Ou parecia familiar, por ser análoga (como acredito) às práticas brasileiras?

Entre os iorubás, casar significava, acima de tudo, a união de duas grandes famílias ou linhagens, não somente a simples união de dois indivíduos. A conexão entre as famílias começava quando a menina e, possivelmente, também o menino, eram ainda crianças, com o noivado formal sendo celebrado na puberdade da menina. A partir desse momento, a infidelidade dela seria julgada adultério. Festas animadas, extravagantes, jubilantes, e ofertas de sacrifício marcavam o noivado. Nesta cerimônia, chamada idana, a família do noivo oferecia à família dela dois tipos de nozes de cola, pimenta mbongo (pimenta da costa), junto com tecido e dinheiro - tudo isso quando se tratava de famílias prósperas e extensas. É importante notar que idana não é o mesmo que dote que, no sentido brasileiro, significa aquela propriedade dotada à mulher por sua família quando ela se casa. A idana, pelo contrário, é um presente da família do noivo para a da noiva visando celebrar e confirmar a ligação entre ambas. O casamento previa dias de preparo com cânticos, batuque e dança, ocasião em que a noiva, assisti-

\footnotetext{
54 "Barracas, Barracões, e Barraquinhos, 1846, 1847, 1850, 1853, 1857, 1861 e 1863-1865", AGC-RJ, Códice 58-3-36, fls. 14, 15; Julian Pitt-Rivers, "Honour and Social Status", in J. G. Peristiany (ed.), Honour and Shame: The Values of Mediterranean Society (Chicago: University of Chicago Press, 1966), p. 19.
} 
da por uma tropa de virgens, era banhada, perfumada, vestida e então entregue à casa de sua nova família. A noite de núpcias era um teste. Se não fosse casta, ela era publicamente humilhada e punida, mas, se seu marido a julgasse "digna", então mandava "lindos cauris brancos para a mãe da noiva" e à noiva dava "corais e outras contas caras, e colares de ouro". Uma aliança de casamento podia trazer vantagens para ambos, marido e mulher. Ao proporcionar a entrada em outra família, relações comerciais eram estendidas para o benefício da mulher empreendedora, ou um marido podia contar com os sogros para ajuda ou aconselhamento nos negócios, ou para organizar uma expedição, ou travar uma batalha na guerra. A mulher, tendo sua posição na sociedade como filha na linhagem do pai e como esposa na linhagem do marido, pertencia à família deste por toda a vida, mesmo se viúva. Todavia, ela podia recusar-se a casar. Indispensável para todos os casamentos iorubás, independente de estarem arranjados há muito tempo, era o consentimento da mulher (exatamente como para os dois parceiros no casamento católico). Se desistisse, mesmo no último minuto, a idana era devolvida e o noivado desfeito. ${ }^{55}$

Henriqueta e Rufino romperam com os costumes iorubás quando se amasiaram antes de casar, mas esses não eram tempos normais. Eles eram escravos num país estranho, desprovidos de uma família, de parentes e de suas vilas. Dificilmente podiam replicar no Brasil um casamento elaborado ao modo iorubá, durando anos, pontuado com presentes caros e com mais atenção à família do que ao noivo e à noiva. Porém, Henriqueta tinha, havia muito tempo, planejado seu casamento e, num gesto extravagante, contratado uma carruagem para levar os noivos à igreja e trazê-los de volta à casa, com amigos e vizinhos acenando para eles! Se alguma promessa de casamento tivesse sido feita por $\mathrm{Ru}-$ fino ou Henriqueta nas suas terras natais, a escravidão abruptamente a cancelara e, em todo caso, a lei católica do Brasil simplesmente ignorava os casamentos africanos. ${ }^{56}$

55 Johnson, History of the Yorubas, pp. 113-7, 115 (citações); Bowen, Central Africa, pp. 3034; Denzer, "Yoruba Women", pp. 3-4; Sandra T. Barnes, "Ritual, Power, and Outside Knowledge", Journal of Religion in Africa, v. 20, n. 3 (1990), p. 252. Agradeço a comunicação de Toyin Falola sobre a idana.

56 Divórcio, 1856, fl. 39; Constituições primeiras, 1853, Liv.1, Tít. 71, para. 304. 
É claro que nem toda família iorubá podia patrocinar casamentos suntuosos. Se uma mulher pobre estivesse trabalhando para pagar os juros de um débito de sua família - a expressão usada era "fazendo serviço de devedor", uma prática muito bem regulada - o homem poderia pagar a dívida, libertando-a e permitindo que se casasse com ele. Contrato de pagamento ou penhor, iwofa em iorubá, referia-se a uma pessoa que prestasse serviço a um credor, ao invés de pagar juros sobre um empréstimo. As circunstâncias que ocasionavam o empréstimo podiam ser de coerção - a pobreza, a devastação da guerra, as onerosas obrigações religiosas ou funerárias -, mas a condição do penhor, sendo voluntária e contratual, era distinta da escravidão. O casamento de uma filha com a família do credor era, geralmente, uma forma de cancelamento de um débito, que gerava um casamento subserviente no qual a esposa não tinha a autonomia e a autoridade de uma mulher que casasse com o oferecimento da idana. ${ }^{57}$ Embora, quando libertou Rufino, Henriqueta tivesse invertido os papéis convencionais de gênero, teria ela, por outro lado, seguido um costume iorubá, embora modificado, ao livrá-lo do débito e da escravidão, para que pudessem se casar decentemente?

O divórcio vinha, também, com as regras próprias dos iorubás. A concessão do divórcio não era uma decisão sacerdotal, mas secular, feita pelos chefes da vila para o caso de uma mulher que cometia adultério com algum parente do seu marido ou de um marido que infligia extrema crueldade à sua esposa. Nessa sociedade altamente consciente de regras quanto ao débito, o endividamento crônico também era causa para o divórcio, junto com o roubo compulsivo. Sobre a possibilidade de dissolução do casamento, os iorubás criavam uma exceção para a poligamia. Uma vez separada, a mulher iorubá divorciada não podia se casar novamente enquanto seu ex-marido vivesse, mas o homem iorubá divorciado ficava com as mulheres que já tinha. Violência física, dívida, pagamento de dívida, indissolubilidade do matrimônio - esses também são, afinal, os temas da petição de divórcio católico de Henriqueta.

57 Johnson, History of the Yorubas, pp. 126-31; E. Adeniyi Oroge, "Iwofa: An Historical Survey of the Yoruba Institution of Indenture", African Economic History, v. 14 (1985), pp. 75, 79-86, 91; Toyin Falola e Paul E. Lovejoy, "Pawnship in Historical Perspective", in Toyin Falola e Paul E. Lovejoy (eds.), Pawnship in Africa: Debt Bondage in Historical Perspective (Boulder: Westview Press, 1994), pp. 1-26, esp. 11-2; Robin Law, "On Pawning and Enslavement for Debt in the Pre-Colonial Slave Coast”, in Falola e Lovejoy (eds.), Pawnship in Africa, pp. 55- 69. 
Segundo os costumes iorubás, como é que as posses de um casal eram divididas? A lei civil brasileira, diferentemente da britânica ou da norte-americana, tratava as posses conjugais como propriedade comum, a menos que ambos os cônjuges tivessem assinado um acordo pré-nupcial separando tudo ou parte do que possuíam e do que adquiririam ou herdariam. O divórcio permitia a divisão conforme os termos desse acordo. Chama nossa atenção que, uma esposa e um marido iorubás fossem donos, separadamente, de seus próprios bens e ganhos, tanto durante o casamento como depois do divórcio. "Toda mulher", o missionário Bowen notou em 1849, "é independente e trabalha para si mesma e se sustenta", sem direito à propriedade do marido, assim como ele não tem nenhum direito à dela. Uma mulher, divorciando-se, juntava tudo que era dela - panelas e jarras de água, tecidos, contas, bodes, carneiros e aves e voltava para sua família, a menos que ela fosse acusada de adultério e obrigada a devolver a idana. As dívidas dele continuavam sendo dele e cada pedacinho de riqueza dela ficava com ela ${ }^{58}$ Em uma cidade iorubá, Henriqueta teria ficado em melhor situação - livre das dívidas e na posse de seus bens, talvez até mesmo da sua corrente de ouro.

Vergonha causada pelo escárnio público era uma forte punição entre os iorubás. ${ }^{59}$ Talvez fosse o que Henriqueta quisesse para Rufino, quando abriu dois processos na Justiça e suportou - e o forçou a suportar - o escrutínio público, vergonhoso, do casamento e do dinheiro deles.

\section{Famílias inventadas}

O costume iorubá atribuía às mulheres total responsabilidade, dentro e fora do casamento, de cuidar dos filhos, o ponto alto da honra feminina. As mulheres se orgulhavam de si mesmas por suportarem a dor e os perigos do parto. Aqui, Bowen fez uma observação intrigante: embora fosse uma "grande desgraça não ter filhos, as mulheres iorubás não eram prolíferas" e, comumente, eram totalmente estéreis. ${ }^{60}$ Nem Henriqueta, nem sua amiga mina Joaquina tiveram filhos, um detalhe que

58 Johnson, History of the Yorubas, pp. 99, 116; Bowen, Central Africa, pp. 304-5; Código Philippino, 1870, Liv. 4, Tít. 94, nota 4.

59 Iliffe, Honour in African History, p. 116.

${ }^{60}$ Bowen, Central Africa, p. 305; Iliffe, Honour in African History, p. 80. 
parece sem importância, exceto por poder se encaixar num padrão maior. A historiadora Sheila Siqueira de Castro Faria, usando testamentos do início do século XVIII até meados do século XIX, constatou que as mulheres minas, tanto as casadas como as amasiadas, tiveram poucos filhos e a maioria - $78 \%$ - não teve nenhum. ${ }^{61}$

As mulheres minas também eram excepcionais, como confirma Faria, em pagar por sua liberdade em dinheiro, como Henriqueta o fez, mais do que as outras mulheres africanas e muito mais frequentemente do que as escravas nascidas no Brasil. Representando apenas cerca de $7 \%$ de todos os escravos do Rio de Janeiro, elas se destacavam por ser $15 \%$ de todas as africanas libertas. Uma mulher livre podia economizar comprando pouco a pouco joias (especialmente ouro), talvez imóveis, porém, com mais frequência, uma ou duas escravas ganhadeiras. Até o fim da vida, ela podia vir a acumular uma modesta - ou não tão modesta - fortuna, e se preocupava com o que fazer desses bens.

Aqui, Faria descobre uma estratégia notável entre as mulheres minas do Rio de Janeiro, que se utilizavam - parece - tanto de costumes iorubás como brasileiros para passarem a ter poder como chefe de família. Se ela fosse solteira, divorciada ou viúva, e não tivesse filhos, não estava sujeita à obrigação de deixar um testamento, mas, na falta de um documento como este, sua propriedade ficaria para o Estado brasileiro. Quando queria que sua opinião prevalecesse, ela preparava um testamento, e muitas o fizeram. Mas aqui vem a surpresa. Frequente e impressionantemente, a mulher mina do Rio de Janeiro escolhia para o papel de herdeiro a filha de uma de suas escravas, provavelmente cria da casa. Além de ser libertada gratuitamente, essa ex-escrava podia receber um legado - joias, dinheiro - para começar uma nova vida. As mães escravas dessas meninas não desfrutavam de tão boa situação, e sua liberdade geralmente era alcançada somente depois de elas pagarem o preço de avaliação, e um filho desta do sexo masculino valia

${ }^{61}$ Sheila Siqueira de Castro Faria, "Sinhás pretas, damas mercadoras: as pretas minas nas cidades do Rio de Janeiro e de São João del Rey, 1700-1850" (Tese para concurso de Professor Titular, Universidade Federal Fluminense, 2004), pp. 180-91, 191-208 (aqui somente as mulheres do Rio de Janeiro são referidas); Mariza de Carvalho Soares descobre que a maioria dos devotos (minas) de Santo Elesbão declararam em seus testamentos que não tinham filhos, "O império de Santo Elesbão", p. 74. 
ainda menos e podia ser vendido para pagar as dívidas ou as despesas do funeral da dona. ${ }^{62}$ Em 1808, a ex-escrava Ana Maria do Espírito Santo, solteira e sem filhos, escolheu Teodora, a filha crioula de sua escrava Maria, como sua única herdeira. Ela tinha criado a menina como se fosse sua própria filha e tinha por ela um "grande amor". Uma das outras duas filhas da escrava, xará da dona e libertada por Ana Maria no seu nascimento, recebeu uma pequena quantia em dinheiro. Se qualquer uma destas mães escravas teve um filho homem, ele não foi mencionado. Angélica, uma das mães, recebeu permissão para comprar sua liberdade e a outra mãe ficou sob custódia dela, Angélica. Ana Maria claramente favoreceu as filhas de sua escrava, e uma delas em especial. ${ }^{63}$

Essas não eram práticas convencionais brasileiras, mesmo que coubessem perfeitamente nas leis do País. Originam-se de muitas regiões do oeste africano. Praticadas entre as mulheres da era pré-colonial de Edo e Igbo, a sudeste da região iorubá e além do rio Níger, e também a oeste, entre os daomeanos e, a nordeste, os nupes, como também entre iorubás, essas relações femininas se chamam "casamento de mulher com mulher”. As mulheres iorubás, apesar de sua extraordinária independência econômica, ampla influência política e religiosa em potencial e deveres maternos essenciais, não herdavam bens dos pais ou maridos, e suas próprias propriedades eram passadas somente para filhos homens. Elas eram, além disso, impedidas de liderar linhagens, a ordem fundamental da sociedade sendo por descendência patriarcal ou, no caso de famílias extensas, de membros da família que reivindicavam descendência de um antepassado masculino comum. ${ }^{64}$

${ }^{62}$ Faria, "Sinhás pretas", p.. 128, 129 (Tabela 9), e 130 (Tabela 10), 180-208, capítulos 5 e 6; Juliana Barreto Farias e Flávio dos Santos Gomes, "Descobrindo mapas dos minas: alforrias, trabalho urbano e identidades, 1800-1915", in Farias, Soares e Gomes (orgs.), Labirinto das nações, pp. 118-21; Código Phillipino, 1870, Liv. 4, Títs. 46, 47, 88, e 96.

63 Ana Maria do Espírito Santo, "Testamento", 1808, Freguesia de Nossa Senhora da Candelária, Rio de Janeiro, Livro de Testamentos e Óbitos (1797-1809), ACM-RJ, fl. 255; Sheila Siqueira de Castro Faria generosamente me cedeu a transcrição desse e de outros testamentos.

${ }^{64}$ Sobre as duas exceções, ver Smith, Kingdoms of the Yoruba, p. 137; mulheres Esan eram limitadas no acúmulo de riqueza, ver Onaiwu W. Ogbomo, "Esan Women Traders and Precolonial Economic Power", in Bessie House-Midamba e Felix K. Ekechi (orgs.), African Market Women and Economic Power: The Role of Women in African Economic Development (Westport: Greenwood Press, 1995), pp. 7-8; Okojie, Ishan Native Laws, p. 89; Johnson, History of the Yorubas, pp. 95-96. 
O casamento de mulher com mulher possibilitava a uma mulher dar a idana para "casar" com uma jovem, que vinha viver com ela, e a mais velha se tornava um "marido fêmea", que escolhia um homem para se relacionar com a jovem e ter filhos. Tendo dado a idana, quaisquer crianças eram reconhecidas como legalmente pertencentes ao "marido fêmea" e se tornavam suas herdeiras. A "esposa," recebedora da idana como qualquer outra mulher, diferia das esposas comuns somente por ser uma pessoa de fora, vinda de outra vila. A prática foi comparada à "compra de um escravo", ou seja, a compra de alguém sem família ou linhagem. Ao criar sua própria linhagem feminina, o "marido fêmea" garantia a transferência de sua propriedade para os herdeiros que escolhesse e podia projetar seu controle sobre a propriedade para além de sua vida. Nessas famílias inventadas, rótulos de gênero foram flexivelmente designados, e sexo e gênero nem sempre correspondiam. O casamento entre duas mulheres se tornou a solução, no início do século XIX, para o crescente rendimento das mulheres e a determinação destas para gerir seus próprios bens. ${ }^{65}$

É impossível traçar, precisamente, a trajetória dessas práticas até o Brasil, mas ela pode ter começado já na própria África, via comerciantes que viajavam por terra, rios e rotas costeiras, via refugiados em tempos de guerra, via escravização e, por fim, via o comércio transatlântico de escravos ao longo do século XVIII e primeiras décadas do XIX. Modificado para se adequar às circunstâncias locais, uma versão simplificada desse tipo de casamento possivelmente se tornou uma estratégia adotada pelas mulheres minas que, libertas da escravidão, procuravam com energia sua independência. ${ }^{66}$

${ }^{65}$ Faria, "Sinhás pretas", pp. 232-44; Okojie, Ishan Native Laws, p. 89; ver também Ogbomo, "Esan Women Traders", p. 17, e os mapas que constam no livro; Smith, Kingdoms of the Yoruba, pp. 4, 5, 105-8; Amadiume, Male Daughters, Female Husbands, pp. 7, 17, 21, 31, 34-5, 39, 47-98, 125-7; os homens também invertiam parentesco e gênero, instituindo filhas como filhos e herdeiros do sexo masculino para conservar terras na família na ausência de filhos homens biológicos, pp. 31-34.

${ }^{66}$ Law, Oyo Empire, pp. 4-5, 7, 126-9, 133, 209, 217, 218, 6 e 213 (mapas); Smith, Kingdoms of the Yoruba, pp. 19, 47, 49, 70-3, 93, 105-9, e 121-3; Ogbomo, "Esan Women Traders", pp. 1-21, e mapa, p. 16; Melville J. Herskovits, "A Note on 'Woman Marriage' in Dahomey", Africa: Journal of the International African Institute, v. 10, n. 3 (1937), pp. 335-36; Beth Greene, "The Institution of Woman-Marriage in Africa: A Cross-Cultural Analysis", Ethnology, v. 37, n. 4 (1998), pp. 395-412. 
Joaquina, a amiga de Henriqueta, possuía pelo menos alguns escravos (mas se eram mulheres ou homens, não é dito) que, provavelmente, trabalhavam na venda de quitandas, como ela. A dificuldade era que, embora não tivesse filhos, Joaquina era casada e possuía bens em conjunto com seu marido. Somente se morresse, ela podia, sozinha, libertar e tornar suas escravas ou as filhas destas suas herdeiras. Henriqueta queria comprar uma escrava, mas desistiu por falta de dinheiro. No entanto, ela provavelmente nunca desistiu dessa ambição, e agora, sem um marido e com uma clara habilidade para poupar dinheiro, teria ela eventualmente assumido o papel de "marido fêmea" na sua própria família fictícia? Em lugar nenhum consegui encontrar seu testamento, contendo suas últimas vontades. Contudo, sabendo que, no lado brasileiro do Atlântico, pelo menos algumas minas libertas seguiam essa prática, podemos plausivelmente imaginar que Henriqueta tivesse em mente esse modo africano de perpetuar sua linhagem e manter sua propriedade por meio de uma família feminina inventada. ${ }^{67}$

No Brasil, a identidade mina de Rufino assumiu significados locais, enquanto ele fazia sua transição de escravo para liberto. Ao adotar para si uma versão do nome do seu senhor, uma prática muito frequente, ele se tornou o africano liberto Rufino Maria Baleta. No entanto, certamente, nunca perdeu a memória de infância, de quando sua identidade mina foi gravada em sua pele. A identidade é sequencial, cumulativa e dependente de memórias guardadas e recordadas. Para Henriqueta, tanto quanto para Rufino, a origem iorubá nunca foi totalmente apagada, mesmo quando novas experiências brasileiras, circunstâncias, entendimentos e reações eram adicionados e a memória aprofundada. Os passados deles também não eram totalmente idiossincráticos, mas foram cerzidos de

${ }^{67}$ Divórcio, 1856, fl. 4; Faria, "Sinhás pretas", caps. 5 e 6; aguardando exames dessa natureza estão os testamentos de escravas libertas do século XIX, em Salvador, Bahia, muitas delas eram nagô, primeiramente descritas por Kátia M. de Queirós Mattoso, "Testamentos de escravos libertos na Bahia no século XIX: uma fonte para o estudo de mentalidades", Centro de Estudos Baianos, v. 85 (1979), pp. 1-53; para um exemplo baiano, ver Roza do Ó Freire, Testamento, 1863, Salvador, Bahia, Registro de Testamento, Livro 43 (1863-1864), Seção Judiciário, APEB, fls. 50-52. 
memórias partilhadas e de outras escutadas de outros minas e absorvidas como próprias. Com paciência e sorte, alguma coisa desses passados possíveis, sobrepostos e lembrados podem ser recuperados, devolvendo aos cativos seus passados africanos e reconhecendo o lugar de peso da memória na contínua formação e reformulação da identidade.

\title{
Texto recebido em 24/01/2011 e aprovado em 14/03/2011
}

\begin{abstract}
Resumo
Através das experiências de dois africanos ocidentais enviados à Bahia como escravos, provavelmente em torno de 1840, e depois vendidos para o Rio de Janeiro onde eles se conheceram, tornaram-se amantes, compraram sua liberdade, se casaram e se divorciaram, discuto o debate contínuo sobre o remodelamento ou transferência de identidades étnicas africanas em sociedades escravistas americanas. As fontes deste caso brasileiro sugerem que identidades prévias não eram subitamente apagadas; ao invés disso, novas camadas de compreensão e modos de reagir eram adicionados. Qualquer que fosse a dinâmica da formação cultural, era a memória que ligava de forma crucial as distâncias entre o passado que eles carregavam e o presente para o qual tinham sido empurrados. E assim torna-se esclarecedor reconstruir os passados africanos plausíveis de serem lembrados nos quais esse casal tentava buscar sentido para um presente brasileiro nada familiar.
\end{abstract}

Palavras-chave: mina - iorubá - escravos - libertos - divórcio - gênero

\begin{abstract}
Through the experiences of two West Africans shipped to Bahia as slaves, probably in the 1840s, then sold south to Rio de Janeiro where they met, became lovers, bought their freedom, married, and divorced, I comment on an ongoing debate over the re-fashioning or transfer of African ethnic identities in American slave societies. The sources in this Brazilian case suggest that previous identities were not suddenly erased, but rather new layers of understanding and ways of responding were added. Whatever the dynamic of cultural formation, it was memory that crucially bridged the distance between the past they carried with them and the present into which they were thrust. And so it becomes illuminating to reconstruct the plausibly remembered African pasts on which this couple drew to make sense of an unfamiliar Brazilian present.
\end{abstract}

Keywords: mina - Yoruba - slave - freed - divorce - gender 